\title{
WAR AND INTERNATIONAL ADJUDICATION: REFLECTIONS ON THE 1899 PEACE CONFERENCE
}

\author{
By David D. Caron*

\section{INTRODUCTION}

In fact, the first organized communities of international law ... are organizations the function of which is to settle conflicts.

Hans Kelsen

But here we shall note the recurrence of a paradox.... Where practice is least ethical, theory becomes most utopian.

Edward Halle't Carr

The belief that a world free of war might be possible, be more than simply a dream, is a relatively recent phenomenon. ${ }^{3}$ In earlier times, war-like disease-was a part of life. There existed then a fatalism about war that no doubt persists in many parts of the world today. During the nineteenth century, however, parts of the world developed a confidence in progress and a hope that progress might extend to the abolition of war. Most importantly for this essay, a popular belief circulated at the end of the century that the establishment of a permanent international court would be an important step toward a world free of war. Ad hoc arbitration, as distinct from adjudication by such a permanent court, was not the same and, by itself, not enough. The 1899 Peace Conference was a point of inflection, a turn in the river, in the effort to move beyond ad hoc international arbitration to adjudication by a permanent international court as a means to avoid war and preserve international peace and security.

One hundred years later, the legacy of the 1899 conference continues most obviously in the institution it created, the Permanent Court of Arbitration. But the spirit that drove the negotiations in 1899 may be said more importantly and directly to have continued in the Permanent Court of International Justice and its successor, the International Court of Justice. A similar spirit and belief in the rule of law animated the chain of developments leading up to the 1998 Rome Conference on the International Criminal Court. Indeed, in the sense that the 1899 conference was not an isolated event but, rather, the first in a series of such conferences (the second Hague Conference took place in 1907 and the third, scheduled for 1915, was canceled as a consequence of the First World War), the legacy of the process begun in 1899 may be viewed most broadly as the continuing refinement of international organization for the maintenance of peace and security.

\footnotetext{
" Of the Board of Editors.

'HANS Kelsen, LAWAND PeaceinInternational Relations:'THe Oliver Wendell Holmes Lectures 1940-41, at 149 (1942).

2 EdWaRd HalletT CARR, THE TwENTYYEARs' CRISIS, 1919-1939, at 174 (Harper Torchbook 1964) (1939).

${ }^{3}$ See, e.g., HeNRY SumNER MAINE, INTERNATIONAL LAW-ThE WHEWELl LECTURES 8 (London, J. Murray1888) ("War appears to be as old as mankind, but peace is a modern invention").
} 
To go forward, it is often wise, and sometimes necessary, to go back. The purpose of this essay is to renew our sense of the 1899 conference in terms both of what happened then and of how those events, beliefs, and objectives manifest themselves today. This essay looks back to war and peace at the end of the nineteenth century, to how those ideas were understood and how it was thought that arbitration and judicial settlement of disputes were to play a role in ensuring a more peaceful world. Very different views were held about the rhetoric of peace at the end of the nineteenth century and by the delegates to the 1899 conference. Some seriously doubted that legal settlement of disputes could prevent wars; while the effort might be admirable, perhaps even useful, it was in their view fundamentally naive. Others, such as Lord Balfour of Great Britain, saw the construction of "paper screens," i.e., treaty regimes addressing security, as dangerous in that they could mislead people about the likely turn of events. ${ }^{4}$ The then-active peace movements and others strongly believed, however, that states could renounce war and instead accept judicial settlement of disputes. ${ }^{5}$ Peace would be gained by constructing the machinery of peace rather than the tools of war.

In examining the legacy of the 1899 conference in this century and what it suggests for the decades ahead, it is important to recognize frankly at the outset that difficult, probably unanswerable, questions are presented. These questions concern the relations between war, its causes, and the capacity of an international court to free humanity from the increasing horror of war. The answers are elusive because one cannot prove what would have happened had there been no international court or had there been one that more fully met the vision of those who sought it. ${ }^{6}$

It is also important to emphasize that the raison d'être of the 1899 Peace Conference was not dispute resolution but, rather, the avoidance of war. In this sense, this essay does not deal broadly with the resolution of all international disputes, but with the resolution of those disputes most intimately tied to the security of the state-those most likely to result in the use of armed force on a wide scale, that is, the hard cases. ${ }^{7}$ Likewise, rather than attempting to address all means of peaceful resolution of disputes, this essay focuses on legal mechanisms to resolve disputes. ${ }^{8}$ Finally, all this is not to say that only questions of war come before the International Court of Justice. That is most certainly not the case. Rather, it is to say that the International Court of Justice is the inheritor of the belief that a permanent court occupies a central place in any international system of order and in one's hope for the future of that system. ${ }^{9}$ This belief is the fundamental legacy of the 1899 Peace Conference.

\section{WAR, PEACE, AND INTERNATIONAL ARBITRATION IN THE NINETEENTH CENTURY}

To understand the debates of the 1899 Peace Conference, one must appreciate the spirit of the nineteenth century and the contemporary concern about the growing horrors of war,

\footnotetext{
'Philip Kerr, The Mechanical Reason for War, in PHILIP KERR \& LIONEL CURTIS, THE PREVENTION OFWAR7, 14-15 (1923) (quoting Lord Balfour).

${ }^{5}$ It is beyond the scope of this essay to trace the efforts of various groups to have states renounce war as an instrument of national policy, although it should be emphasized that the peace movements often linked the promotion of an international court with a call for the formal renunciation of war. See generally HANS WEHBERG, THE OUTLAWRY OF WAR (1931); DENYS D. MYERS, ORIGIN AND CONCLUSION OF THE PARIS PACT: THE RENUNCIATION OF WAR AS AN INSTRUMENT OF NATIONAL POLICY (1929); JAMES T. SHOTWELI, WAR AS AN INSTRUMENT OF POLICY AND ITS RENUNCIATION IN THE PACT OF PARIS (1929).

${ }^{6}$ The art of counterfactuals is rarely satisfying to those who hold the opposite belief. See, e.g., VIRTUAL HISTORY: ALTERNATIVES AND COUNTERFACTUALS (Niall Ferguson ed., 1998), and debate concerning the volume.

${ }^{7}$ This focus likewise characterizes PEACEFUL Resolution OFMAJOR INTERNATIONALDISPUTES (Julie Dahlitzed., 1999).

${ }^{8}$ Other methods of peacefully settling disputes discussed at the 1899 conference, such as conciliation and factual inquiry, cannot be addressed within the narrow confines of this essay. For a comprehensive general bibliography, see DAG HAMmarskJōld LibRARY, PEACEFul SETTLEMENT OF DisPUTES BETWEEN STATES: A SELECTIVE BIBLIOGRAPHY, UN DOC. ST/LIB/SER.B/39 (1991).

${ }^{9}$ See, e.g., the panel discussion, particularly the remarks of Georges Abi-Saab, in INCREASINGTHEEFFECTIVENESS OF THE INTERNATIONAL COURT OFJUSTICE 202-05 (1997).
} 
the concomitant drive for peace, and the belief that international arbitration, if improved through the establishment of a permanent court, offered the promise of ending war.

An important caveat regarding the discussions of the nineteenth century recounted in this essay is that they primarily involved Europeans and were global only in the sense that the century was a European one. Indeed, the discussions were often premised on an explicitly nonuniversalist perspective. For many, the nineteenth century meant progress: technologically, economically, and materially. Combined with Christian views of human nature, "progress" encompassed the notion that people and the world were capable of salvation. ${ }^{10}$ In this sense, the discussions leading up to, as distinct from those that took place at, the Hague Peace Conference should primarily be seen as having originated within a context emphasizing the concerns of Europe, and resting on Christian beliefs and Western civilization. ${ }^{11}$ Many of the peace movements of the nineteenth century were explicitly based on Christian beliefs. The Quakers, for example, believed that Christianity required some degree of individual pacifism. William Ladd, in his influential 1840 Essay on a Congress of Nations, repeatedly asserts that shared Christian beliefs will provide the foundation on which international order may be built. ${ }^{12}$ Indeed, Ladd would have limited participation in his proposed congress and court of nations to the Christian and civilized nations. ${ }^{13}$ The European focus also manifested itself, for example, in contemporary estimations of whether the nineteenth century was to be viewed as violent or at peace. Thus, John Fiske, writing in 1894 and noting that the Napoleonic Wars, the last significant European conflict, had ended in 1815, could speak of the long peace of the nineteenth century without any reference to the violence in colonial areas. ${ }^{14}$

Finally, it should be recalled that the world at the end of the nineteenth century was changing rapidly and was already vastly different from what it had been one hundred, or even only fifty, years earlier. The arrival of the Industrial Revolution in many countries had led both to increased interaction among states through trade and investment and to an increased capacity for the conduct of war. The Concert of Europe, particularly in the first half of the century, had served the security needs of Europe reasonably well. But as the United States emerged as a world power with particular influence in the Western Hemisphere and political circumstances within Europe shifted, the informal Concert of Europe no longer seemed adequate for the organization of European, not to mention international, security. Within the United States and elsewhere, the emergence of the progressive movement, which called for reform of political structures, led to the creation of the modern

${ }^{10}$ See generally REIIGION AND INTERNATIONAL LAW (Mark W. Janis \& Carolyn Evans eds., 1999).

Thus, at this time modern prisons were born and, in some instances, termed penitentiaries. See, e.g., George Fisher, The Birth of the Prison Retold, 104YAIE L.J. 1235 (1995). Similarly, at this time the compassionate image of colonialism's mission, championed, for example, by Kipling, was probably at its peak.

${ }^{11}$ Notmany non-European states attended the first Hague Conference, but the perspective of those present had a modest effect on the substantive outcome regarding the laws of war. See JOSEPH H. CHOATE, THE TWO HAGUE PEACE CONFERENCES 16-17 (1913). For a sweeping discussion of the interaction of civilization:, see SAMULL P. HUNTINGTON, THE GLASH OF GIVILIZATIONS AND THE REMAAING OF WORLD ORDER (1997).

${ }^{12}$ WILLIAM LADD, ESSAYONA CONGRESSOFNATIONSFOR THE ADJUSTMENT OF INTERNATIONAL DISPUTES WTTHOUT RESORT TO ARMS 102 (Oxford University Press 1916) (1840). For Ladd, peace could only be established through the teachings of Christianity: "The storm of war would soon be hushed in Christendom, and that main obstacle to the conversion of the heathen being removed, Christianity would soon spread all over the world." Id.

${ }^{13} \mathrm{Id}$. at 4-5. This focus was reflected somewhat in the choice of nations that were later invited to and attended the 1899 Peace Conference. Having said this, I also note that a much broader representation of states attended the 1907 Hague Conference and that as this representation in international organizations has expanded considerably in the course of the 20th century, the basic tenets of international adjudication have proved to be nearly universal.

${ }^{14}$ See Kerr, supra note 4, at 10.

As to the significant number of armed conflicts occurring within colonies in contrast to the few intra-European armed conflicts in the 19th century, see EVANLUARD, WAR IN INTERNATIONAL SOCIETY: A STUDYIN INTERNATIONAL SOCIOLOGY 59-60 (1987). See also Antony Anghie, Finding the Peripheries: Sovereignty and Colonialism in NineteenthCentury International Law, 40 HARv. INT'L L.J. 1 (1999). 
bureaucratic state and parallel international institutions. By the end of the century, the framework of modern international organization was beginning to take shape and the need to codify international law was increasingly recognized.

\section{The Peace Movements and "The Specter of War"}

The face of war changed in the nineteenth century. Many at the end of the twentieth century may find it difficult to recapture the glorification of war of earlier centuries. On the one hand, a romantic image of war can be viewed as a perverse luxury of a nobility protected by armor and chivalry. On the other hand, a romantic image of war may simply reflect acceptance of what, as stated earlier, was as much a part of life as disease. In a Native American story, a child is told during a thunderstorm that the wind takes the weak and old wood away from the forest and thus brings renewal and strength. ${ }^{15}$ So, too, was war described as strengthening a culture; war in this view swept away degeneracy and offered renewal. ${ }^{16}$ But, even if a romantic tension between creation and destruction could ever mythically have been said to exist, the world itself was changing and destruction threatened to overshadow all who existed and all that had been built. Technology magnified the power of weapons in the nineteenth century, while mass propaganda demonized the intended targets. Destruction was possible on a scale wider than ever before, and this breadth of scale was matched by an increase in the size of the contesting forces. ${ }^{17}$

A powerful symbol of this changing face of war can be found on the grounds of the Peace Palace, the physical legacy of the 1899 Peace Conference ${ }^{18}$ Behind the palace in The Hague is a stand of trees and cut into those trees is a space perhaps fifteen feet across and a hundred feet deep. At the end of that space stands a statue. To view the statue, one must step from the sunlight into this shaded space, one must commit oneself. But with each step, one discovers that he or she is approaching a chilling representation, "The Specter of War," which embodies the horrors of the First World War, of a generation and innocence lost. ${ }^{19}$

The nineteenth century saw the advent of the mass production of war, with the U.S. Civil War often described as the first modern war in this regard.$^{20}$ As the scope of loss increased, so did popular suspicion of the purposes or wisdom of those who led their peoples to such slaughter. That war could simply be the result of a mistake was widely thought possible in the case of the sinking of the Maine and the Spanish American War, which followed. ${ }^{21}$ And the senselessness of war was emphasized in literature of the day such as Leo Tolstoy's War

${ }^{15}$ FORREST CARTER, THE EdUCATION OF LITTLE TREE (1986).

16 "This is one reason for the uncompromising rejection [by Germany before the FirstWorld War] of the pacifist leanings in the Western World. They were despised and ridiculed as degenerate as compared with the medieval ideal of chivalry." FRITZFISCHER, WAROFILLUSIONS: GERMANPOLICIESFROM 1911 TO 1914, at 81 (M.Jackson trans., 1975) (1969). "One does not have to subscribe to Fischer's thesis to conclude that the very favorable light in which German policy-makers viewed war exercised a subtle but important influence on their behavior." RICHARD N. LEBOW, BETWEEN PEACE AND WAR: THE NATURE OF INTERNATIONAL CRISIS 253 (1981).

17 "When Russia was rising to the height of military reputation ... in 1812 and 1813 , she had always a difficulty in bringing as many as 100,000 men into the field; now she is said to contain six millions of armed men." MAINE, supra note 3 , at 5 .

${ }^{18}$ On the building that came to house the Permanent Court of Arbitration, see A. LYSEN, HISTORY OF THE CARNEGIE FOUNDATION AND OF THE PEACE PALACE AT THE HAGUE (28 Bibliotheca Visseriana, 1934); and ARTHUR EYFFINGER, THE PEACE PALACE-RESIDENCE OF LEARNING, DOMICILE FORJUSTICE (1988). The completion of that building in 1913 was soon to be overshadowed by the First World War.

${ }^{19}$ The statue is titled "Le Spectre de la Guerre." It was sculpted by Rebeca Matte de Iniguez and donated to the Peace Palace by the government of Chile.

${ }^{20}$ Likewise, the U.S. Civil War and other conflicts of that time prompted the development of the modern laws of war. See, on the Lieber Code, Theodor Meron, Francis Lieber's Code and the Principles of Humanity, in POLITICS, VALUES AND FUNCTIONS: INTERNATIONAL. LAW IN THE 21ST CENTURY 249 (Jonathan I. Charney et al. eds., 1997). See also Thomas G. Bames, Introduction to RICHARD SHELLY HARTIGAN, LIEBER's CODE AND THE LAW OF WAR 3 (1995).

${ }^{21}$ See Thomas Allen, Remember the Maine? NAT'L GEOGRAPHIC, Feb. 1998, at 92; see also CHOATE, supra note 11, at 28. 
and Peace. It was amid, and as a promoter of, this intellectual climate, that the peace movements grew in strength during the nineteenth century.

The significance of the peace movements to the 1899 Peace Conference could perhaps be overstated, but it cannot be overlooked. ${ }^{22}$ If the second half of the twentieth century was marked by grass-roots support for deep ecology, human rights, and women's rights, then the second half of the nineteenth century was marked by antislavery movements, the women's suffrage movement, and, most importantly for this essay, the peace movements. ${ }^{29}$

Like today's environmental movements, the peace movements encompassed many different strands and philosophies. To some adherents, peace meant simply a world free of war. To others, peace meant a world that remained at peace because it was guided by programs or philosophies of social justice. Some viewed violence as morally wrong and saw peace as a goal for both society and the individual. It is in this strand that some branches of contemporary pacifism find their roots. For others, peace required organizational restructuring so as to avoid the most serious breach of peace-war.

Individuals, through their ideas and force of will, wielded great influence over the peace movements and were the driving force behind them. And if, as the editors of this symposium indicate, women were not among the delegates to the 1899 Peace Conference, ${ }^{24}$ they certainly stood at the center of some of the peace movements. ${ }^{25}$ The highly popular novel, Lay Down Your Arms, by Baroness Bertha von Suttner, for example, was to the promotion of peace what Uncle Tom's Cabin was to the abolition of slavery. ${ }^{26}$

\section{Arbitration and the Peaceful Settlement of Disputes in the Nineteenth Century}

A distinctive feature of the nineteenth-century peace movements was their faith in international arbitration, and particularly adjudication before a permanent international court, as a promising means to advance peace. Since these movements could have chosen other strategies to promote peace, their focus on a permanent international court deserves attention. ${ }^{27}$ While contemporary observers are likely to believe that adjudication and mediation

\footnotetext{
22 The peace movements have been studied in detail. A classic work of the time credited by many later writers is A. C. F. BEALES, THE HISTORY OF PEACE: A SHORT ACCOUNT OF THE ORGANIZED MOVEMENTS FOR INTERNATIONAL PEACE (1931); see also THE EAgLE AND THE DOVE: THE AMERIGAN PEACE MOVEMENT AND UNITLD STATES FOREIGN POLICY 1900-1922 (John Chambers II ed., 2d ed. 1991); CHARLES CHATFIELD, THE AMERIGAN PFACE MOVEMENT: IDEALS AND ACTIVISM (1992); M. E. CURTI, THE AMERICAN PEACE CRUSADE 1815-1860 (1929); C. ROLAND Marchand, THE AMERIGAN PEACE MOVEMENT AND SOCIAL ReForm 1898-1918 (1972); Christina PHELlPS, THE ANGLO-AMERICAN PEACE MOVEMENTS IN THE MID-NINETEENTH CENTURY (1930); M. R. VESNIC, DEUXPRECURSEURS FRANCAIS DU PAGIFISME (1911). A basic reference is ROBERT S. MEYER, PEACE ORGANIZATIONS PAST AND PRESENT: A SURVEY AND DIRECTORY (1988). A particularly valuable collection of materials relating to many of the American peace movements from their inception may be found at Swarthmore College, and may be viewed in part at <http://www.swarthmore.edu/library/peace/>.

On contemporary "peace studies" and their ties to the peace movements, see Peace Studies: Past and Fulure, ANNALS AM. ACAD. POL. \& SOC. SCI., July 1989 (George A. Lopez spec. ed.).

${ }^{23}$ This is not to imply that there was not also substantial grassroots (nongovernmental organization) support for environmental causes toward the latter half of the 19th century. See, e.g., KURKPATRICK DORSEY, THE DAWN OF CONSERVATION DiPLOMACX: U.S.-CANADIAN WILDLIFE PROTECTION TREATIES IN THE PROGRESSIVl: ERA (1998).

${ }^{24}$ See George H. Aldrich \& Christine M. Chinkin, Introduction to Symposium, The Hague Peace Conferences, $94 \mathrm{AJIL}$ 1,1 (2000).

${ }^{25}$ See generally UNITED NATIONS LiBRARY AT GENEVA, BERTHA VON SUTTNER AND OTHER WOMEN IN PURSUIT OF PEACE (1993).

${ }^{26}$ See BRIGITTE HAMANN, BERTHA VON SUTTNER: A LIFE FOR PEACE 72 (Ann Dubsky trans., Syracuse University Press 1996) (1986) (originally published in German as Bertha von Suttner: ein Leben für den Frieden) (asserting that "[j] ust as the latter did more for the abolition of slavery than all the scientific arguments put together, so did Suttner contribute more to the spread of the pacifistidea throughout the world than what the pacifists had hoped for in vain for decades."); see also MEMOIRS OF BERTHA VON SUTTNER: THE RECORDS OF AN EVENTFUL LIFE (authorized Eng. trans., 1910); BEATRIX KEMPF, SUFFrAGETTE FOR PEACE: THE LIFE OF BERTHA VON SUTTNER (R. W. Last trans., Oswald Wolff 1972) (1964) (published in German as Bertha von Suttner-Das Leben einergrossen Frau).

${ }^{27}$ Not all explanations reflect well on either the peace movements or the desirability of an international court. It is argued persuasively, for example, that the Austrian Peace Society founded and led by Baroness von Suttner promoted international courts to the exclusion of other rationally related policies because doing so presented a
} 
may facilitate the resolution of disputes between parties that genuinely wish to avoid conflict, these same observers would probably find it difficult to recreate the profound and widespread nineteenth-century faith in the peacekeeping ability of an international court.

Arbitration had reemerged as a device of international relations at the end of the eighteenth century, when it was used in the Jay Treaty of 1794 between Great Britain and the United States. ${ }^{28}$ This form of international dispute resolution proceeded to enjoy a renaissance in the nineteenth century, culminating in, for many, a particularly important event, the Alabama arbitration of 1871-1872, whose success served to deepen even further the widespread enthusiasm and support for international adjudication. ${ }^{29}$

The Alabama, a British-built Confederate privateer, successfully harassed the Union during the U.S. Civil War by plundering and then sinking sixty-five Union merchant ships. For this and other assistance provided to the insurgent Confederacy, the United States alleged that Great Britain had violated its obligations of neutrality and interfered in American domestic affairs. The ensuing Alabama arbitration was somewhat exaggeratedly credited with defusing the potential conflict between the United States and Great Britain. ${ }^{30}$

The Englishman filled his glass and was about to propose a toast [to the group gathered near Lake Geneva], when the servant-maid came in and handed him a telegram. ... Then the dark, steel-blue evening sky was cut through by a streak of light, and above the low-lying Savoy shore there rose a rocket of enormous size. ... Then there spread out something like a white cloud which assumed a four-cornered rectangular shape, a flag of white fire; a moment after there was another report, and on the white flag appeared a red cross.

All the party sprang up and hastened into the veranda.

"What does that mean?" exclaimed Herr von Bleichroden, startled.

$\cdots$

"Ladies and gentlemen!" said the Englishman ... . "this means, according to the telegram which I have just received, that the first International Tribunal at Geneva has finished its work; this means that a war between two nations, or what would have been worse--a war against the future, has been prevented; that a hundred thousand Americans and as many Englishmen have to thank this day that they are alive. The Alabama Question has been settled not to the advantage of America, but of justice, not to the injury of England, but for the good of future generations." 31

A whirlwind of events from 1889 onward fed popular support for an international court. The first International American Conference was held in Washington, D.C., in 1889-1890, producing a Convention for an American International Court, which U.S. Secretary of State Blair celebrated as a "Magna Charta which abolished war and substitutes arbitration between the American Republics, as the first and great fruit of the International American Conference." 32 The Interparliamentary Union was formed in 1889, and promptly and energetically joined the call for arbitration and the creation of a world court. ${ }^{33}$ President

politically safe agenda in Austria at that time. See Richard Laurence, The Peace Movement in Ausiria, 1867-1914, in DOVES AND DIPLOMATS: FOREIGN OFFICESAND PEACEMOVEMENTS INEUROPEAND AMERICAIN THE TWENTIETH CENTURY 20 (Solomon Wank ed., Contributions in Political Science No. 4, 1978); see also PHELPS, supra note 22, at 45-46.

${ }^{28}$ For a history of modern arbitration, see JACKSON RALSTON, INTERNATIONAL ARBITRATION FROM ATHENS TO LOCARNO (1929).

${ }^{29}$ For a memoir by a close observer of the arbitral settlement of the Alabama claims, see THOMAS WILLING BALCh, THE AlABAMA ARBITRATION (1900).

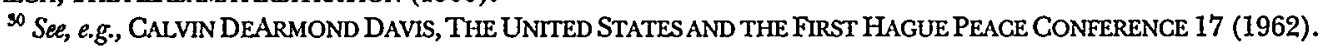

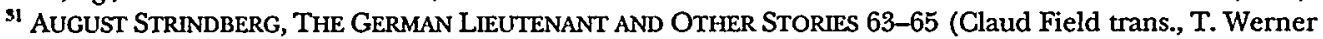
Laurie 1915). For a critical British view of the Alabama arbitration, see MAINE, supra note 3, at 216-18.

${ }^{32}$ The Evolution of OURLATIN-AMERICANPOLICY:ADOCUMENTARYRECORD 58 (James W. Gantenbein ed., 1950).

${ }^{35}$ See generally JAMES L. TRYON, THE INTERPARLIAMENTARY UNION AND ITS WORK (1910). 
Cleveland and Secretary of State Olney persuaded Great Britain to refer a boundary dispute with Venezuela to arbitration in $1896,{ }^{34}$ while Olney and Sir Julian Pauncefote, the British ambassador to the United States, negotiated a general Anglo-American arbitration treaty, both agreements being signed in $1897 .{ }^{35}$ The U.S. Senate was not enthusiastic about either an international court for the Americas or the British-American arbitration accord, but its decisions to with hold its advice and consent did not diminish the growing popular support for arbitration at the time. This spirit infused the first inaugural address of President. McKinley in 1897, when he stated that a defining feature of U.S. foreign policy had been its insistence on "the adjustment of difficulties by judicial methods rather than force of arms."

The enthusiasm for ad hoc arbitration, however, does not in itself explain the push for a permanent international court. Although the nineteenth century had witnessed a resurgence of arbitration, the record was also replete with failures. Often parties could not agree to arbitration in a timely manner, or one of the parties would question the validity of an award by issuing self-judging declarations of nullity. ${ }^{37}$ Structural solutions were sought. Strategies were adopted to prevent declarations of nullity, for example, by designating a foreign head of state as arbiter to discourage claims of bias. To facilitate the establishment of tribunals, focus was placed on reducing the risk that the various points of negotiation between the parties would derail an arbitration: the initial commitment to arbitrate (which in turn was dependent on the identity of the arbitrator(s) or the process by which such person(s) would be selected), the definition of the question to be decided, and the specification of the law to be applied to the dispute. Numerous groups, such as the Institut de Droit International, drafted codes of arbitration so as to strengthen the practice of ad hoc arbitration. ${ }^{38}$

For the peace movements, the answer to noncompliance with the results of ad hoc arbitration lay in strengthening the stature of the institution so that its decisions would command greater respect. The American peace movements took as their model for this institution the U.S. Supreme Court, which in the nineteenth century was viewed as an institutional innovation that had bridged the transition from the Articles of Confederation to the Constitution by serving as arbiter between the states.

Numerous individuals and professional associations devised either structural solutions to ad hoc arbitration or alternative mechanisms that would not present its perceived inadequacies. These efforts built momentum toward the creation of an international court. Certainly, the seventeenth and eighteenth centuries had seen the publication of several highly visible tracts in favor of peace and proposing plans of international governance. ${ }^{39}$ But the nineteenth century brought plans that particularly tied the creation of an international court to the promotion of peace. Two individuals deserve particular mention inasmuch as they ably promoted, often tirelessly, the idea and value of such an institution: William Ladd and Ivan Bloch. Ladd's influential Essay on a Congress of Nations for the Adjustment of International Disputes without Resort to Arms linked the peace movements, in which he was a

\footnotetext{
${ }^{34}$ See Clifton J. Child, The Venezuela-British Guiana Boundary Decision of 1899, 44 AJIL 682 (1950).

${ }^{85}$ See Nelson M. Blake, The Olney-Pauncefote Treaty of 1897, 50 AM. HiST. REv. 231 (1945).

${ }^{36}$ Views of President McKinley, 1897, in 1 A LEAGue OF NATIONS 21, 22 (1918). DAVIS, supra note 30, at 19, describes U.S. foreign policy at the end of the 19th century as marked by a strange duality of global imperial power and advocacy of world peace.

${ }^{37}$ The definitive work on nullity is W.MICHAEL REISMAN, NULUTYYAND REVISION: THEREVIEW AND ENFORCEMENT OFINTERNATIONAL JUDGMENTSANDAWARDS (1971). Nullification and review was subsumed in the clebate on Article 55 at the 1899 Hague Peace Conference, which is not discussed in this essay. Readers are directed to Reisman's excellent treatment of the period and debate, $i d$. at $29-46$.

${ }^{38}$ For an overview of these efforts, see $i d$. at 30-34 ("a steady stream of codes").

${ }^{59}$ See, e.g., ThOMASW. Balch, EMERICCRUCE (Allen, Lane, \& Scott 1900); William PENN, TowafdSTHE PRESENT AND FUTURE PEACE OF EUROPE (American Peace Society 1912) (1694); IMMANUEL KANT, PERPETUAL PEACE: A PHILOSOPHICAL SKETCH (Bobbs-Merrill 1957) (1795);JEAN-JACQUES ROUSSEAU, PROJEGT OF PERPISTUAL PEACE (E. M. Nuttall trans., Cobden-Sanderson 1927); ABBÉ DE SAINT PIERRE, ABRÉGÉ DU PROJET DE PAIX PERPÉTUELLE (H. Bellot trans., Sweet \& Maxwell 1927) (1738).
} 
prominent figure, with the concept of an international court. ${ }^{40}$ The second writer of great influence was Ivan Bloch. His six-volume work, The Future of War, in Its Technical, Economic and Political Aspects, provides the most direct bridge between the peace movement's fascination with international adjudication and the 1899 Hague Peace Conference. Both of these men and their work deserve closer inspection. ${ }^{41}$

Ladd grew up with the peace movement in the United States and by numerous accounts was an inspiring lecturer on its behalf. His Essay was published in 1840 , shortly before his death. In it, Ladd proposed the establishment of two international institutions, a "Congress of Nations" and a "Court of Nations," whose combined efforts would govern world affairs and promote peace among all nations. ${ }^{42}$ The congress of nations would be

a congress of ambassadors from all those Christian and civilized nations who should choose to send them, for the purpose of settling the principles of international law by compact and agreement, of the nature of a mutual treaty, and also of devising and promoting plans for the presentation of peace and meliorating the condition of man. ${ }^{43}$

The court of nations would be "composed of the most able civilians in the world, to arbitrate or judge such cases as should be brought before it, by the mutual consent of two or more contending nations."

The members of the court of nations would be appointed by the congress of nations. ${ }^{45}$ In the case of disputed boundaries, the court would dispatch surveyors to collect facts and report back to it. The court would be authorized to offer mediation when war actually existed or whenever tensions arose between two or more nations, endangering the peace. Verdicts would be reached by a majority vote. Decisions would be made within the confines of existing treaties. Where there was no treaty, the case would be treated with equity and justice.

Ladd simply assumed, as did the peace movements about much of their work, that the court, if created, would bring about the end of war. In general, this assumption was based on his faith in the power of "public opinion." He writes: "Public opinion is daily becoming more powerful . . .; for 'great is the truth, and it will prevail,' and finally triumph for ever over brute force." 46

The work of Ivan Bloch, in circulation in the early 1890s and published in full in 1898, is more directly linked to the Hague Conference. The literature is enlivened by a minor tempest concerning whom to credit with the tsar's 1898 circular that gave rise to the conference. One persuasive and thorough account concludes that it is inaccurate to attempt, as does much of the contested literature, to give credit to this or that person. As is almost always the case, reality tends to be more complex. But it can be said with confidence that Tsar Nicholas II knew Bloch's work in detail, and admired it to the point of having extended discussions with Bloch on several occasions. ${ }^{47}$ Bloch's The Future of War was particularly

19 LADD, supra note 12.

41 IVAN BlOCH, The FutURE OF WAR IN ITS TECHNICAL, ECONOMIC AND POLITICAL Relations (1898) (6 vols.).

${ }^{12}$ Ladd also reviews the history of previous attempts at establishing such courts, for their positive and negative aspects. See LADD, supra note 12, at 38-60.

${ }^{13} I d$. at $\mathrm{xxxix}$.

${ }^{44} I d$.

${ }^{45} I d$. at $34-37$.

${ }^{46}$ Id. at 91 .

${ }^{17}$ For a complete discussion of Tsar Nicholas II's knowledge of and access to Bloch's work, see PETER VAN DEN Dungen, The Making of PEACE:JEAN DE Blochand THE First HAgue PEACE. CONFERENCE (Occasional Papers No. 12, Center for the Study of Armament and Disarmament, Calif. State Univ. Los Angeles, 1983) (explaining that Bloch "had published the first results of his inquiries in 1892 in Russian and Polish periodicals" and concluding that "the evidence demonstrates clearly that Nicholas II was familiar with de Bloch's theory and showed great interest in it a long time before he published his Manifesto"). Id. at 4, 9. For more on Bloch, his work, and his role in the 1899 conference, see Emile Joseph Dillon, The Tsar's Eirenicon, CONTEMP. REv., Nov. 1898, at 609, reprinted in ARBITRATIONOR WAR: CONTEMPORARYREACTIONSTO THE HAGUEPEACE CONFERENCE OF 1899 (Sandi E. Cooper ed., 1972); and Thomas K. Ford, The Genesis of the First Hague Peace Conference, 51 POL. SCI. Q. 354 (1936). Dillon refers to Bloch by the Polish spelling of his name, Bliokh. Others refer to him as Jean de Bloch, a reflection of the dominance of the French language in diplomacy at that time. 
significant because of the rigor and method he brought to the subject. Born in a modest, if not poor, state in what is now Poland, Bloch became a successful banker and ultimately head of a railroad. In the latter role, he aided in the preparation of railroad-based supplycontingency plans in the event of war. ${ }^{48}$ But as he turned his mind and broad learning toward the problem of war, he came to the conclusion that war as an instrument of national policy was obsolete, that victory in war was rapidly becoming impossible. ${ }^{49} \mathrm{He}$ explored this thesis by bringing the scientific method-the preferred approach of that positivist era-to bear on the questions of war and peace.

The result was his belief in "the impossibility of war." With amazing clarity, he foresaw both the waste and the anarchy that would come with the First World War. The future war would be fought in trenches, and with great armies and commensurate losses. The war would last as long as economies redirected to that end could last. But before that breaking point was reached, there would be famine and social revolution. There would be no victor in this war. As Edmund Blunden would write of the First World War, "[ $t$ ] he War had won, and would go on winning. ${ }^{250}$ For Bloch, it was not a question of whether international adjudication could be used to avoid war; rather, in his view nations had to be brought to understand that it must be used to avoid war.

Though Bloch's writing was influential, not all professed the same enthusiasm for an international court. In 1887, shortly before his death, Sir Henry Maine, professor of international law at the University of Cambridge, delivered his Whewell Lectures. As suggested by Whewell when he established the chair, Professor Maine through his lectures considered rules and measures "as might tend to diminish the evils of war and finally to extinguish war among nations." ${ }^{n 1}$ The last of these lectures, the twelfth, concerned proposals to abate war.

Noting that the "belief" in compulsory international arbitration "is being wiclely extended in our day," certain measure of success to international arbitrations, and there is much reason to wish them an extended sphere." ${ }^{53}$ He cautioned, however, that "before this or any other country commits itself to arbitration as a universal remedy for war, one or two of its defects ought to be specially noticed." ${ }^{54}$ Most importantly, Maine stressed that, unlike domestic arbitration, which has behind it the coercive force of the courts, international arbitration between "disputant sovereigns" lacks such enforcement power.$^{55}$ Further, while in domestic settings the stature of the arbitrator might render coercion unnecessary, in Maine's view it had been "many centuries since such authority was attributed to any man or class in international matters." "[ $t]$ he want of coercive power is, in fact, the one important drawback which attends all attempts to improve International Law by contrivances imitated from the internal economy of states . . . like the administration of law by organized tribunals." ${ }^{\text {7 }}$

Still, Maine did not oppose the establishment of an international court, but he supported it primarily because he thought it would be preferable to the then-existing reliance on ad hoc arbitration. Maine found the composition of ad hoc tribunals to be quite

\footnotetext{
${ }^{48}$ As described in BARBARA W. TuCHMAN, THE GuNS OF AUGUST (1962), such railroad plans for both offensive and defensive military operations were all the rage in continental Europe at the end of the 19th century and the start of the 20th.

${ }^{49}$ Ladd took a similar view, but without the data supplied by Bloch. "Mankind have tried war long enough," in Ladd's view, "to know that itseldom redresses grievances, and that it generally costs more than the redress is worth, even when it is most successful; and 'that,' to use the words of Jefferson, 'war is an instrument entirely inefficient toward redressing wrong; . . . it multiplies instead of indemnifying losses.' LADD, supra note 19, at 96.

${ }^{50}$ Quoted in WAR AND THE PTTY OF WAR 7 (Neil Philip ed., 1998).

${ }^{51}$ MAINE, supra note 3, at 1 .

52 Id. at 211 .

${ }^{53} I d$. at 213.

${ }^{54} I d$. at 211.

${ }^{55} I d$. at 212-13.

${ }^{56} \mathrm{Id}$. at 213.

${ }^{57}$ Id.
} 
unsatisfactory. ${ }^{58} \mathrm{He}$ appears to have been principally concerned about the tendency of such tribunals to focus on the matter before them, rather than the system of international law generally. He summarized his view thus:

Such a court would not be free from the infirmity which afflicts all such additions to the international system. It would have no force at its back. But I think it would be better constituted. I think it would be more free from prejudice, and would soon be recognised as freer, than the present occasional adjudicators. And I think it could be better trusted to adjust its awards to the entire body of international principles, distinctions, and rules. ${ }^{59}$

The conviction that a court required force at its back can also be found in the views of those who were required to fight to defend national interests. Alfred Thayer Mahan, a U.S. Navy captain and member of the U.S. delegation to the 1899 Hague Conference, wrote almost immediately after the close of the conference that "men forget what they have owed, and still owe, to the sword." ${ }^{10}$ Similarly, Gen. William Tecumseh Sherman, who is remembered for the march across Georgia that sped the end of the U.S. Civil War, attended a dinner in 1890 celebrating the centennial of the U.S. Supreme Court and afterwards wrote to a fellow officer:

From 1861 to 1865 the Supreme Court was absolutely paralyzed: their decrees and writs were treated with contempt south of the Potomac and Ohio, they could not summon a witness or send a Deputy Marshall. War, and the armed Power of the Nation, alone removed the barrier and restored to the U.S. courts their lawful jurisdiction. Yet, from these honied words of flattery, a stranger would have inferred that at last the lawyers of America had discovered the sovereign panacea of a Government without force. . .

I was in hopes the Civil War had dispelled this dangerous illusion, but it seems not. ${ }^{61}$

General Sherman's caution has merit. The conclusion that war is no longer an acceptable tool of national policy does not in and of itself mean that pacifism, rather than military preparedness, is the best means to avoid the waste and suffering of armed conflict.

It was in this context, the contested edge of a dream, that an international peace conference was convened in 1899.

\section{PREPARING For PEACE: WAR AND THE 1899 PeACE CONFERENCE}

Shortly before the close of the last century, an event took place which the friends of peace greeted with jubilation, triumph even. ... It was regarded as an event as epochmaking as the Congress of Vienna, held almost a hundred years before.

Beatrix Kempf 62

\footnotetext{
${ }^{58}$ MAINE, supra note 3, at 214-15.

${ }^{39}$ Id. at 219.

${ }^{60}$ AlFRED T. MAHAN, LeSSONS OF THE WAR WITH SPAIN 237 (Little, Brown 1899). Going further, Mahan argued the moral case for noncompliance in some instances by drawing on the civil disobedience literature of the time:

If, on the one hand, there is solid ground for rejoicing in the growing inclination to resort first to an impartial arbitrator, if such can be found,... there is, on the other hand, cause for serious reflection when this most humane impulse ... shall vitally impair the moral freedom, and the consequent moral responsibility, which are the distinguishing glory of the rational man ....

Id. at 208-09. For an introduction to Mahan's life and influence on naval warfare, see A Strategy of Sea Power and Empire: Stephen B. Luce and Alfred Thayer Mahan, in RUSSELI F. WEIGLEY, THEAMERICAN WAY OF WAR: A HISTORY OF UNITED STATES MILITARYSTRATEGYAND POLICY 167 (1993). Mahan's emergence as a great naval thinker was by no means early in his life and was, even then, unexpected, perhaps even to him. A comprehensive study is W.D. PULESTON, THE LIFE AND WORK OF ALFRED THAYER MAHAN (1939).

${ }^{61}$ Letter from General W. T. Sherman to General Meigs (Feb. 5, 1890), reprinted in MAHAN, supra note 60, at 237-38.

${ }^{62} \mathrm{KEMPF}$, supra note 26 , at 42.
} 
At The Hague the Diplomats, the Lawyers and the Humanitarians or Pacifists-the latter term came to be used shortly after this date-came together for the first time. It was the dress rehearsal of Open Diplomacy. The Diplomats did not relish it.

$$
\text { Alfred Zimmern }{ }^{6 s}
$$

The 1899 conference was called to address issues of war and peace. In the initial Russian circular of August 1898 proposing the conference, the two foci of effort were to be disarmament and peaceful settlement of disputes. ${ }^{64}$ But the historical record clearly shows that the proposals concerning disarmament were nonstarters from the outset. The new agenda items on the laws of war in the Russian circular of January 1899 were more amenable to producing agreement, but for opponents of war these proposals were anathema, making war less horrific rather than peace more likely. This shift in emphasis was evident in the restrained opening address by Baron de Staal of Russia, the president of the conference. Although de Staal said that the purpose of the conference was to mitigate the horrors of war and to create mechanisms for diplomacy, ${ }^{65}$ he went on to emphasize that

$[w]$ e owe it to humanity ... we owe it to ourselves, to accomplish a useful work. ... We should keep in view the possible, and not attempt to seek for abstract ideals. Without at all sacrificing our ulterior hopes, we should remain within the realm of reality and test it to its lowest depth, so as to lay solid foundations and build on concrete bases. ${ }^{66}$

Almost only in the area of international dispute resolution could enough negotiating space be found for progress to be made. Indeed, it was in this last respect that the conference would achieve the most success, even though it would not attain the high goals set for it by the peace movements. ${ }^{67}$

The 1899 conference met from May 23 to July 24, 1899, and undertook its work in three commissions. ${ }^{68}$ The First Commission dealt with armaments; the Second Commission, the laws of war. The goals of the Third Commission were those proposed in the Russian circular:

To accept in principle the employment of good offices, of mediation and facultative arbitration in cases lending themselves thereto, with the object of preventing armed conflicts between nations; to come to an understanding with respect to the mode of applying these good offices, and to establish a uniform practice in using them. ${ }^{69}$

${ }^{63}$ ALFREd ZimmerN, THE LEAGUe OF NATIONS AND THE Rule OF LAW 1918-1935, at 103 (1936).

${ }^{64}$ The 1899 Peace Conference is well documented in the literature. Primary sources include GHOATE, stipra note 11 (the author served as the U.S. First Delegate to the second Hague Peace Conference); DAVIS, supra note 30; JOHN W. FOSTER, ARBITRATION AND THE HAGUE COURT (1904) (the author was president of the National Arbitration Conference and prepared this work at the request of the MohonkArbitration Conference); WILLLAM I. HULL, THE TwO HAGUE CONFERENCES (1908) (the author was, in his words, an American "journalistic representative" at the second Peace Conference, and a professor of history at Swarthmore Collegc); Margaret Robinson, Arbitration and the Hague Peace Conferences of 1899 and 1906 (1936) (unpublished Ph.D. dissertation, University of Pennsylvania); JAMES BROWN SCOTT, THE HAGUEPEACE CONFERENCESOF 1899 AND 1907 (1909) (2 vols.); BARBARA W. TUCHMAN, THE PROUD TOWER: A PORTRATT OF THE WORLD BEFORE THE WAR 1890-1914 (1966); and ANDREW WHITE, AUTOBIOGRAPHY OF ANDREW DICKSON WHITE (1905) (2 vols.) [hereinafter WilrTE, AUTOBIOGRAPHY] (thatportion of the autobiography dealing with the first Hague Peace Conference was reprinted as ANDREW D. WHITE, THE FIRST HAGUE CONFERENCE (1912) [hereinafter WHITE, CONFERENCli]).

The record of the conference is detailed and preserved and is enhanced, as noted, by several personal memoirs. Internal sources might overstate the significance of the meeting. The broader historical record, however, confirms that the participating governments took the conference very seriously. The great importance they attached to it is also apparent in the stature of the delegations appointed to represent them.

${ }^{65}$ See 1 SCOTT, supra note 64 , at 51.

${ }^{66}$ HULL, supra note 64, at 37-38 (quoting Baron de Staal). Andrew White, who served as president of the American delegation to the 1899 conference, wrote in this tone of limited expectations that "[a]t the outset $I$ was skeptical as to the whole matter." 2 WHITE, AUTOBIOGRAPHY, supra note 64, at 250.

${ }^{67}$ In Hull's view, for example, the establishment of a permanent court of international arbitration was considered the crowning achievement of the first Peace Conference. HuLL, supra note 64, at 475 .

${ }^{68}$ See 2 WHITE, AUTOBIOGRAPHY, supra note 64, at 263-340 (entries for May 23-July 24, 1899).

${ }^{69}$ Russian Circular (Jan. 11, 1899), reprinted in 2 SCOTT, supra note 64, at 4-5. 
The pace over this two-month period was luxurious by today's standards. The Third Commission held nine "reunions," from May 23 to July 5. Its "committee of examination" held eighteen meetings from May 26 to July 21 collecting proposals, editing drafts, and writing the final version of the convention. ${ }^{70}$ Headed by its president, Léon Bourgeois of France, the Third Commission included such other distinguished principal delegates as Count Nigra of Italy, Sir Julian Pauncefote of Great Britain, and Andrew White of the United States.

Representatives of various nongovernmental organizations of the day, such as the peace societies ("organized public opinion" in contemporary parlance) went to The Hague and took an active interest in the proceedings of the conference. ${ }^{71}$ Transparency as an issue, if not a phrase, was for them a concern. But the conference delegates were concerned about subjecting themselves to advance criticism while they worked and their meetings thus were held in closed session. ${ }^{72}$ Organized public opinion would have been surprised to learn that it was quite clear from early in the conference that arbitration would not be obligatory and that any court that was established would not be permanently in session.

The Convention Regarding the Pacific Settlement of International Disputes, signed on July 29,1899 , contains sixty-one articles. ${ }^{73}$ Article 1 is a general undertaking by the signatory powers, "[w]ith a view to obviating, as far as possible, recourse to force [through] their best efforts to insure the pacific settlement of international differences." ${ }^{74}$ In the remaining articles, the Convention addresses three basic mechanisms for peaceful settlement of disputes: mediation and good offices, commissions of inquiry, and international arbitration. In the following section, I review the work and major points of the Third Commission's debate on a permanent court at the first Hague Conference and the adjustments and debate that followed at the second Hague Conference in 1907. This part concludes with consideration of the First World War, which forced the cancellation of the third Hague Conference.

\section{The First Hague Conference-An International Court}

Several nations came to the conference with proposals for a permanent international court, some of which had been drafted by professional associations. In the Third Commission, the honor of presenting the initial proposal was held by Sir Julian Pauncefote of Great Britain. ${ }^{75}$ The British plan sought the establishment of a permanent tribunal of international arbitration, to be governed by a code written by the conference. ${ }^{76}$ The United States generally supported this plan, although, at least initially, it wanted a continuously functioning court. ${ }^{77}$ Bourgeois, speaking for France, indicated acceptance of the British proposal, with two conditions: recourse to the tribunal by states would be entirely consensual and states would choose the arbitrators. The Russian plan was distinguished by providing for obligatory arbitration on certain matters and for the explicit codification of the

\footnotetext{
${ }^{70}$ See HuLL, supra note 64 , at 40 .

${ }^{\prime \prime}$ On the role of nongovernmental organizations and the press, see Robinson, supra note 64, at 106-30; and TUCHMAN, supra note $64, \mathrm{ch} .5$.

${ }^{72}$ See 1 SCOTT, supra note 64, at 53. Although representatives of the peace movements could not be involved directly in the conference, on several occasions groups were allowed to present their views. See 2 WHITE, AUTOBIOGRAPHY, supra note 64, at 288 (entry for June 4, 1899). As to the citizen groups present, see ZIMMERN, supra note 63 , at 103 .

${ }^{73}$ Convention [No. 1] Regarding the Pacific Settlement of International Disputes, July 29, 1899, 32 Stat. 1779, 1 Bevans 230 [hereinafter 1899 Hague Convention No. I].

74 For those who sought a renunciation of war, this careful call for "best efforts" "as far as possible" ivas a disappointment. Given its generality, this provision, perhaps needless to say, was not a subject of controversy at the conference. See 1 SCOTT, supra note 64 , at 46.

${ }^{75}$ See 2 WhITE, AUTOBIOGRAPHY, supra note 64, at 271 (entry for May 26, 1899).

${ }^{76}$ See id. at 278 (entry for June 1, 1899).

${ }^{77}$ See id. at 280 (entry for June 1, 1899).
} 
applicable international law in those instances. ${ }^{78}$ These four delegations worked diligently at preparing a composite proposal that would be generally acceptable. ${ }^{79}$

Germany, however, consistently expressed general opposition to arbitration, thus framing the central crisis of the conference. Count Münster, recorded White in his entry for May 24, 1898,

[i]nsisted that arbitration must be injurious to Germany; that Germany is prepared for war as no other country is or can be;... and that neither France, Russia, nor any other power can do this. Arbitration, he said, would simply give rival powers time to put themselves in readiness, and would therefore be a great disadvantage to Germany. ${ }^{80}$

As Germany's opposition apparently hardened, White feared a catastrophe. The faithful adherents of arbitration, he wrote in his entry for June 13, "will go on and do the best we can; but there is no telling what stumblingblocks Germany and her allies may put in our way; and, of course, the whole result, without their final agreement, will seem to the world a failure and, perhaps, a farce." ${ }^{\prime 1}$

Although the delegates for the most part viewed "organized public opinion" as a distraction from the work at hand, ${ }^{82}$ they invoked that opinion in support of the need for action by the conference and particularly in rebuttal to Germany's opposition to arbitration. Both White and William Hull credit the popular demand for an arbitration court as playing a significant role in persuading Germany to back down from its opposition to the idea. ${ }^{89}$ Count Nigra pointed out to German delegate Zorn that "the impatience with which public opinion awaits the results of our labors has become so great that it would be dangerous to renounce the acceptance of an arbitral tribunal." ${ }^{84}$ T. M. C. Asser of the Netherlands and F. F. Martens of Russia also urged the German delegation to consider the pressure of world opinion. ${ }^{85}$ Indeed, delegates in favor of the permanent tribunal argued that its establishment offered the only possibility of providing the world with tangible evidence that the conference had in fact accomplished something. Finally, on June 18, Frederic Holls, secretary of the American delegation, in a story he reportedly often retold, traveled to Berlin with Zorn and a letter from White. Together they met with Baron von Bülow, convincing him that arbitration would not impair German sovereignty, that Germany would not be forced to submit to arbitration, and that failure to agree would harm German-American relations. ${ }^{86}$ Germany eased its position but insisted that an occasional court of arbitration be tested before the establishment of a permanent one. ${ }^{87}$ This condition, in turn, required that the conference reject the Russian proposal for obligatory arbitration on certain specified

\footnotetext{
${ }^{78}$ At the first meeting of the Third Commission, the Russian delegation presented 18 articles. The Russian explanatory note accompanying the articles "pointed out the difference in scope between voluntary and obligatory arbitration." HuLL, supra note 64 , at 299 . The note argues that universal obligatory arbitration is not feasible because the mutual rights and duties of states are determined by " political treaties,' which are nothing else than the temporary expression of casual and transitory relations between diverse national forces." Id. In this view, conflicts arise between nations, not because parties do not agree on how to interpret the law of these treaties, but because they want to amend or completely abrogate the agreement. Therefore, the law of political treaties cannot be applied in the same way as the law made by a legislature within a single nation. This line of thought later resurfaces as the problem of peaceful change. SeePEACEFUL CHANGE:ANINTERNATIONAL.PROBLEM (C.A.Manning ed., 1937); see also JOHN FOSTER DULLES, WAR, PEACE AND CHANGE (1939).

Nevertheless, the Russian delegation went on to argue that there are some disputes that can be submitted to obligatory arbitration, "differences which concern exclusively special points of law, and which touch neither the vital interests nor the national honor of states." HULL, supra, at 299-300.

${ }^{79}$ See HULL, supra note 64, at 300.

${ }^{80} 2$ WHITE, AUTOBIOGRAPHY, supra note 64, at 265 (entry for May 24, 1899).

${ }^{81} \mathrm{Id}$. at 299 (entry for June 13, 1899).

${ }^{82}$ See id. at 349-50 (entry for Aug. 5, 1899).

${ }^{83}$ HULL, supra note 64, at 23.

${ }^{84} \mathrm{Id}$. at 375; 2 WHITE, AUTOBIOGRAPHY, supra note 64, at 299 (entry for June 14, 1899).

${ }^{85}$ See HULL, supra note 64, at 375-76.

${ }^{86}$ See id. at 387; 2 WHTTE, AUTOBIOGRAPHY, supra note 64, at 308-18 (entries for June 16-21, 1899).

${ }^{87}$ See HULL, supra note 64, at 374; and 1 SCOTT, supra note 64, at 77.
} 
matters. ${ }^{88}$ As a practical matter, the German condition led to debate over the name of the new tribunal. The Germans opposed labels such as "court" and "tribunal," proposing instead "Permanent List of Arbitrators." 89 The name ultimately chosen, "Permanent Court of Arbitration," gave something to both camps.

Even as the basic question of Germany's opposition to any tribunal was discussed, two debates dominated the deliberations on the proposed court: first, if there was to be a permanent court, then how were the judges to be selected? and, second, would there be some obligation to refer disputes to arbitration $?^{90}$

The question of how judges would be selected presaged the great difficulties that would resurface with all subsequent discussions of a permanent international court. In 1899 the United States and Russia desired that the court be permanent. ${ }^{91}$ The method of selecting the members of such a court became moot, however, as it became apparent early on that a fixed sitting court would not result from the first Hague Conference. The delegates turned instead to the way the institution would be constituted in particular instances and gravitated quickly toward party control. Great Britain proposed establishing a list of arbitrators from which the parties would form a tribunal, a proposal in keeping with the delegates' tendencies. ${ }^{92}$ The United States proposed that such persons be selected by the highest judicial body in each country, but other delegations objected to this proposition, "partly because of uncertainty as to the highest judicial body in some countries in Europe, and partly because they were opposed to investing their judiciary with any appointive power."93 The Convention as ratified calls for a list of available arbitrators and an administrative system that organizes the tribunals. As to the list, the system adopted provides that "each signatory power shall select not more than four persons of recognized competence in questions of international law, enjoying the highest moral reputation, and disposed to accept the duties of arbitrators." 94

As regards the second issue mentioned above, it also became clear very early in the conference that general acceptance of obligatory arbitration would not be forthcoming. ${ }^{95}$ This conclusion, however, did not foreclose less encompassing forms of acceptance, and the negotiations focused on such possibilities.

A more modest approach to the idea of obligatory arbitration was to create an obligation to refer certain types of disputes to arbitration. The delegates considered limiting the range of disputes subject to this obligation by making an abstract distinction between legal and political disputes. Another means of doing so, which elicited more discussion, was to reach agreement on an enumerated list of types of disputes that were to be subject to obligatory arbitration. ${ }^{96} \mathrm{~A}$ Russian proposal along the lines of an enumerated list explained that obligatory arbitration would not apply to situations that themselves constitute a cause of war but, rather, to situations that contribute to a general atmosphere of unfriendly relations. ${ }^{97}$ As noted earlier, however, this proposal for obligatory arbitration of certain types of disputes was eventually abandoned as the price of Germany's acceptance of the Permanent Court of Arbitration. ${ }^{98}$

\footnotetext{
${ }^{8}$ See 2 WhITE, AurobIOGRAPHY, supra note 64, at 321 (entry for June 23, 1899).

See HULL, supra note 64, at 378.

${ }^{90}$ Various other issues, such as the weight to be accorded a decision, the possibility of appeal, and the rules of the court, were also debated at length but cannot be addressed within the scope of this essay.

${ }^{9 l}$ See 2 WhITE, AUTOBIOGRAPHY, supra note 64, at 278, 290 (entries for June $1 \& 6,1899$ ).

${ }^{92}$ See id. at 278 (entry for June 1,1899 ).

${ }^{93}$ HULL, supra note 64, at 383.

94 1899 Hague Convention No. I, supra note 73, Art. 23. Members of the court serve for a term of six years, and their appointments are renewable.

${ }^{95}$ See FOSTER, supra note 64, at 43; 2 WHITE, AUTOBIOGRAPHY, supra note 64, at 259 (entry for May 19, 1899).

${ }^{96}$ See HuLI, supra note 64, at 327-28.

${ }^{97}$ See id. at 326 .

See id. at 331; 2 WHITE, AUTOBIOGRAPHY, supra note 64, at 316 (entry for June 19, 1899); 1 ScorT, supra note 64 , at 78 .
} 
In a final effort, the Russian delegation proposed obligatory arbitration for one set of disputes, those relating to pecuniary damages suffered by a state or its citizens as a result of the illegal action or negligence of another state or its citizens. ${ }^{99}$ This proposed article failed, together with all the other provisions proposing subjects for obligatory arbitration. Hull states that Martens viewed the failure of this article as especially regrettable inasmuch as these disputes "formed the large majority of disputes submitted to arbitration, and hence have proven themselves especially adaptable to such solution." 100

Another, more modest form of obligation can be found in Article 27 of the Convention: "The signatory powers consider it their duty, in case a serious dispute threaters to break out between two or more of them, to remind these latter that the Permanent Court of Arbitration is open to them." ${ }^{101}$ This provision, presented by the French delegation, was thought necessary because it was assumed that parties to a dispute would not suggest arbitration for fear of displaying weakness. The intervention of a third party would allow states to sidestep this obstacle. ${ }^{102}$ Although the obligation would not be particularly controversial today, it was opposed at the Peace Conference by small states suspicious of how it might be employed. The Balkan states in particular feared that this "duty" would lead to unwelcome intervention by the larger powers and that it would favor the powerful nations, as small nations would not invoke the article with regard to wars involving larger powers. ${ }^{103}$ This obstacle surfaced near the end of the conference. Bourgeois appealed to, and apparently persuaded, the Balkan delegates, reminding them that Article 27 applies only to those disputes that imperil peace, ${ }^{104}$ and that there are no large or small powers in the sense that "all are equal before the work to be accomplished." 105 The U.S. delegation supported the article but came to believe that it conflicted with the Monroe Doctrine, which called for nonintervention by Europe in American affairs. ${ }^{106}$ Ultimately, Article 27 was adopted unanimously, with the American delegation adding to the proceedings a declaration regarding the incompatibility of the article with the Monroe Doctrine. ${ }^{107}$

Despite its name, the Permanent Court of Arbitration created in 1899 was not a permanent court. As noted Dutch scholar Asser would state at the 1907 conference: "Instead of a permanent court, . . . the Convention of 1899 gave only the phantom of a court, an impalpable specter or, to speak more precisely, it gave a secretariat and a list." 108

\section{The Second Hague Conference}

Although arbitration generally, and arbitration before tribunals of the Permanent Court of Arbitration specifically, was employed relatively often between 1899 and 1907, ${ }^{109}$ international peace seemed increasingly elusive: the war between Great Britain and the Transvaal broke out in 1900 shortly after the first Hague Conference, and Russia and Japan went to war in 1904. ${ }^{110}$ Amid this state of affairs, the Interparliamentary Union held its

\footnotetext{
${ }^{99}$ See HuLL, supra note 64, at 349 .

${ }^{100}$ See id. at 350 .

${ }^{101} 1899$ Hague Convention No. I, supra note 73, Art. 27, reprinted in 2 SCOTT, supra note 64, at 95.

${ }^{102}$ See HuLl, supra note 64 , at 305.

${ }^{103}$ See id. at 307. In contrast, the Swiss delegation supported the idea in that it gave neutrals an active role; in essence, neutrals became "peace-managers." See also 2 WHITE, AUTOBIOGRAPHY, supra note 64, at 336 (entry for July 19, 1899).

${ }^{104}$ See Hull, supra note 64, at 308.

105 See id. at 309.

1062 WHITE, AUTOBIOGRAPHY, supra note 64, at 339-42 (entries for July $24 \& 25,1899$ ).

${ }^{107}$ The U.S. Senate did not give its advice and consent to the treaty until March 1902. The story of the ratification is told by DAVIS, supra note 30 , at 186-202. -

${ }^{108}$ HuLL, supra note 64, at 410 (quoting T. M. C. Asser).

${ }^{109}$ See 1 SCOTT, supra note 64, at 126. For a list of the cases decided by tribunals of the Permanent Court of Arbitration between 1899 and 1928 , see Robinson, supra note 64, at 148.

${ }^{110}$ President Roosevelt applied the good offices and mediation clauses in ending the Russo-Japanese War. A commission of inquiry was used in the Dogger Bank incident. See 1 SCOTT, supra note 64, at 125.
} 
annual meeting in St. Louis, Missouri, in September of 1904 and adopted a resolution requesting that the governments of the world send delegates to a second international peace conference. ${ }^{111}$ The union thereupon sent a two hundred member delegation to Washington, D.C., to request that President Roosevelt call the second Hague Peace Conference. ${ }^{112}$ Roosevelt promised to comply but did not do so until after the Russo-Japanese War ended in September 1905, at which time it appears that he decided to leave the honor of formally issuing the call for the second conference to the tsar. The second conference convened in 1907 in The Hague, meeting from June 15 until October $18 .^{113}$ Whereas the only American countries invited to the first conference were the United States and Mexico, all of the Latin American republics were invited to the second conference (increasing the number of "American" governments to nineteen). In total, forty-four of the world's fifty-seven states claiming sovereignty participated in the second conference, an addition that influenced its work. ${ }^{114}$

The much larger second conference was divided into six commissions, numerous subcommissions, and committees of examination. The first commission, formally termed the "I Commission" but often called the "Arbitration Commission," was split into two subcommissions. The first subcommission considered various plans of arbitration; the second, maritime prize. The I Commission held ten reunions. ${ }^{115}$ Its first subcommission met fortyseven times, while the second met only six.

The 1907 conference focused on four objectives relating to arbitration and adjudication: (1) revision of the 1899 Convention for the Pacific Settlement of International Disputes, (2) creation of an international court of prize, (3) conclusion of an agreement on obligatory arbitration, and (4) establishment of a permanent court of justice. ${ }^{116}$ The following sections address each goal, the first two but briefly.

Revision of the 1899 Convention. The second Hague Conference expanded the 1899 treaty from sixty-one articles to ninety-seven. The most notable changes involved adding summary proceedings, ${ }^{117}$ improving the procedures for commissions of inquiry, ${ }^{118}$ increasing the

111 The resolution is reprinted in FOSTER, supra note 64, at 137.

112 See CHOATE, supra note 11 , at 50 .

11 see id. at 55 .

${ }^{114}$ Africa remained unrepresented. Asia was represented by the same four governments as in 1899 . The 20 governments of Europe were represented, as in 1899, with the addition of Norway. See HULL, supra note 64, at 14.

The importance of increased membership can be seen in the extended discussion of the use of force to enforce the collection of debts. At the 1907 conference, Horace Porter of the United States proposed "an agreement to observe some restrictions on the use of force to collect ordinary public debts arising from contracts." He argued that the typical case is that of the capitalist who asks his government to espouse an inflated claim: "Often, such a private party will have bought the debt on the market at a low cost, and then demands payment at par. The Porter proposition was intended to eliminate this cause of friction between States." Id. at 353 (quoting Porter). Interestingly, the most significant opposition to the Porter proposal came from the American republics, principally because they had borne the brunt of forcible collection efforts and felt the proposal did not go far enough. See id. at 358. Luis Drago of Argentina made three objections to Porter's proposal (the so-called Drago doctrine): (1) "that it did not restrict the arbitration of debts arising from ordinary contracts solely to those cases in which the courts of the debtor country had been previously appealed to and refused justice"; (2) "that it seemed to include public debts as subject to arbitration"; and (3) "that it did not absolutely exclude military aggression, or the occupation of American soil, as the result of disputes in regard to public debts." Id. at 358-59. Drago was generally supported by the Latin American states with the exception of Brazil (Barbosa). The Porter proposition became a separate convention (Convention Relating to the Limitation of the Employment of Force for the Recovery of Contract Debts), to avoid the implication that a category of obligatory arbitration had been advanced. See id. at 369-70. The proposition passed with abstentions by Belgium, Romania, Sweden, Switzerland, and Venezuela. Nine American republics adhered with reservations.

${ }^{115}$ See id. at 44.

${ }^{110}$ See 1 SCOTT, supra note 64 , at 124-31.

${ }^{117}$ Convention for the Pacific Settlement of International Disputes, Oct. 18, 1907, Arts. 86-90, 36 Stat. 2199,1 Bevans 577 [hereinafter 1907 Hague Convention No. 1].

${ }^{118}$ Id., Arts. 12-36. 
responsibilities of the administrators of the court, ${ }^{119}$ and making minor improvements in the procedures of the Permanent Court of Arbitration. ${ }^{120}$ In fact, the revisions consisted almost entirely of twenty-two new rules of procedure for the commissions of inquiry. ${ }^{121}$ As for the Permanent Court of Arbitration, the conference unanimously agreed, as a general matter, to maintain it "as it was established by the first Peace Conference." 122

Creation of an international court of prize. Hull writes that a German delegate "electrified the members by declaring his government had instructed him to present to the conference propositions concerning the establishment of an international court to decide on the legality of captures made in naval war." ${ }^{23}$ Why Germany, which had so consistently opposed arbitration at the first Peace Conference, made this proposal is unclear to the author; perhaps it was a feint to draw attention and energy away from other proposals to which Germany would express serious opposition. In any event, Great Britain (which had a plan of its own for such a court) and the United States supported the German proposal. Consensus in favor of the court quickly emerged and debate centered on its operation and relationship to national courts. ${ }^{124}$ As with the Permanent Court of Arbitration, much discussion was devoted to the selection of judges. ${ }^{125}$ The commission ultimately adopted the Convention Relative to the Creation of an International Prize Court by a vote of 27 to 2 (Brazil and Turkey), with 15 abstentions. ${ }^{126}$ (The Court was ultimately not created because agreement could not be reached on applicable law at the 1908 London Conference. ${ }^{127}$ )

An agreement on obligatory arbitration. Bourgeois, the chief delegate of France and president of the I Commission, raised the issue of obligatory arbitration, alluding to the statement of German delegate Zorn at the 1899 conference that, after experiments by pairs of states, the moment might come when obligatory arbitration in certain enumerated cases would be possible. Bourgeois asked whether the opportune moment had not arrived in view of the series of bilateral treaties concluded since 1899 that provided for obligatory arbitration. ${ }^{128}$ While Great Britain, Russia, and the United States joined in the call for obligatory arbitration, ${ }^{120}$

${ }^{119}$ Id., Arts. 15-17, 43, 48, 60.

${ }^{120} \mathrm{Id}$., Arts. 52-85.

121 See HULL, supra note 64, at 291-95. More substantial alterations were not entertained. Russia and the Netherlands proposed that the signatory powers "agree to establish" international commissions of inquiry, instead of merely judging them useful. Yet, despite the two qualifying phrases ("involving neither honor nor independence" and "as far as circumstances permit"), the proposed amendment was vigorousiy rejected. See id. at 289.

122 See id. at 387-89.

${ }^{123}$ Id. at 427.

${ }^{124}$ The delegates debated whether the court should have jurisdiction only between two governments or between one government and individual citizens of another; whether the court should have jurisdiction over all cases of capture or over only those in which neutrals are concerned; when the role of the international court should commence, directly after the national prize courts of first instance have rendered their decision, or not until the highest court in the country has rendered its decision; and whether the court should have a permanent character or be constituted only on the occasion of each war. For a review of the range of debate, see id. at 428-43.

${ }^{125} \mathrm{See}$ id. at 436-41. The British proposed a scheme for the appointment of judges providing that "each of the signatory powers whose merchant marine, on the date of the signature of this convention, is more than 800,000 tons, shall designate one "judge" - hence totaling eightjudges, appointed by Britain, the United States, Germany, Norway, France, Japan, the Netherlands, and Italy - "but if any of these powers should be party to a suit, its appointee would take no part in the decision of the case." Id. at 439. The British proposal would have excluded Russia and Austria, and was rejected.

${ }^{126}$ Convention [No. XII] Relative to the Creation of an International Prize Court, Oct. 18, 1907, 100 BRIr. \& FOREIGN ST. PAPERS 435 (1906-07); see HULL, supra note 64, at 447-48.

${ }^{127}$ See ClYDE EAGLETON, INTERNATIONAL GOVERNMENT 226 (rev. ed. 1948); see also 1 SCOTT, supra note 64, at 131. Scott writes concerning the second Hague Conference: "The one was a court without judges [the creation of a permanent court of justice]; the other is a courtwithout law, because the nations failed to codify international law, and thus supply the court with a code of maritime law to be administered and interpreted by it."

${ }^{128}$ For a summary of the relevant practice, see HELEN MAYCORY, COMPULSORYARBITRATION OF INTERNATIONAL DISPUTES 28-68 (1932).

${ }^{129}$ See HuLL, supra note 64, at 314. 
Germany argued against all of the proposals made at the conference. ${ }^{130}$ Although the German opposition frustrated delegations favoring obligatory arbitration, many believed that by the time of the third peace conference such a treaty would be possible. ${ }^{131}$

As in the first conference, the subject shifted from a general obligation to the possibility of mandatory arbitration in certain specified instances. Some thirty specific categories of disputes were proposed and a list of twenty-four categories voted upon. ${ }^{132}$ The German delegation declared that it would vote against every proposition to establish obligatory arbitration by means of a world treaty. ${ }^{133}$ Baron von Bieberstein argued that obligatory arbitration posed two basic problems: first, it would not be obligatory in practice and, second, the list of specific disputes would create questions of interpretation that would only raise new obstacles to arbitration. With Darwinian overtones, von Bieberstein asserted that ideas should not be imposed artificially but-like a plant-should flourish in accordance with their own strength. "The great ideas destined to rule the world hew their way by their own strength; they flourish and triumph in the sunshine of individual liberty, and they can not endure the shade of general principles, of lists and categories." ${ }^{134}$ Restating the plant metaphor in support of a limited obligation to arbitrate, Dr. Luis Drago of Argentina replied that the matters constituting the list of disputes are but "the first shoots of the sapling which should grow into the great king of the forest." 135

Ultimately, the I Commission took votes on three variations of limited obligatory arbitration. One proposal would have mandated arbitration for "judicial" disputes and those relating to the interpretation and application of treaties, with the qualifications of vital interests, independence, honor, and the interests of third parties. The vote was 35 for the proposition and 9 against. The second proposal would have required arbitration, without any qualifications, for an unspecified list of disputes. The vote was 33 for the proposition and 11 against. The last proposal would have required arbitration, without any qualifications, for a proposed list of types of disputes. The vote in this last instance was 31 for the proposition and 13 against. The nations opposing the proposals always included Germany, Austria, Greece, Romania, and Turkey, and usually Belgium, Bulgaria, and Switzerland. The delegations of Japan, Luxembourg, and Montenegro invariably abstained. Although the proposals gained the support of a substantial majority, the opposition of a considerable number of significant states prevented the necessary degree of consensus. Following the votes, the opposing nations proposed resolutions (voeux) designed to "shelve the whole question" of obligatory arbitration. ${ }^{136}$ The plenary session adopted such a resolution, with abstentions by the United States, Japan, and Turkey. ${ }^{137}$

The attempt to establish a permanent court. The renewed attempt in 1907 to establish a "permanent court, meeting regularly and not to be called together for each specific case,"138 failed as it had in 1899-in this instance ostensibly because of disagreements over which nations should be represented on the court. The question of how judges would be selected for a permanent court, which had lurked in the background at the 1899 conference, burst

\footnotetext{
${ }^{130}$ Baron von Bieberstein of Germany opposed a general treaty of obligatory arbitration, even for a very restricted number of disputes, stating that agreements between two states cannot serve as a model for such a general treaty. See id. at 312-13. Sir Edward Fry of Great Britain supported the idea, stating that a general treaty of obligatory arbitration "will have great importance in history as being the collective expression of the conscience of the civilized world." Id. at 314.

191 See 1 SCOTT, supra note 64, at 128.

${ }^{132}$ See HULL, supra note 64, at 332.

139 See id. at 335.

${ }^{134}$ Speech of Baron von Bieberstein, representative of Germany, quoted in id. at 340 .

${ }^{135}$ Speech of Dr. Luis M. Drago, representative of Argentina, quoted in id. at 341.

${ }^{136}$ See HuLL, supra note 64, at 345.

137 See id. at $347-48$.

${ }^{138}$ CHOATE, supra note 11 , at 77.
} 
to the fore in 1907. There were numerous proposals. Argentina, for example, suggested that the conference adopt a method of selecting judges based on "William Penn's plan of apportioning representation according to the amount of the foreign commerce of each state." 139 The impasse arose, however, as Mexico, Serbia, Haiti, Venezuela, Brazil, Bulgaria, Romania, and Uruguay insisted on absolute international equality in the appointment of judges. As Clyde Eagleton noted, "[E] ach state demanded a judge upon the bench-fortyfour in all!"140 The "Powers"- as they were then called-had assumed that they, but not all nations, would have a judge on the court. Joseph Choate and James Brown Scott, members of the U.S. delegation, proposed a method of selection based on classifying states according to differences in population, language, and jurisprudence, but were opposed in this regard by Ruy Barbosa of Brazil and others.

Absent final agreement, but wishing to memorialize the extent of agreement attained, Great Britain proposed a resolution stating that " $[t]$ he conference deems it desirable that the signatory powers adopt the project for the establishment of a Court of Arbitral Justice, with the exception of the rules which have to do with the nomination of judges and their rotation in office." ${ }^{141}$ The resolution was adopted, with slight modifications, by a vote of 38 to 3 (Switzerland, Belgium, and Romania voting against). The defeat of the permanent court, an initiative championed by the U.S. delegation, was the conference's most conspicuous failure, but already many delegations were looking to the third Hague Conference with hope that the permanent court would be agreed to then.

\section{The First World War and the Unrealized Third Hague Conference}

The Hague Conferences came to be seen as a process rather than as events. It was a process that not only addressed arbitration, but also would have led in time to substantial codification efforts. Indeed, even participants in the first Hague Conference clearly did not think that that meeting would be the end of the matter. The American delegation, for example, wrote in its final report that the Permanent Court of Arbitration was "a thoroughly practical beginning" from "which a better and better system will be gradually evolved." ${ }^{42}$ This sense of process was institutionalized by the end of the second conference, when the date of the third conference was fixed and a preparatory committee set up. ${ }^{143}$ As noted, however, the First World War forced the cancellation of the third conference. This cancellation was commented upon poignantly at the time on a memento from The Hague. Since the completion of the Peace Palace in 1913, postcards have sent its image around the world. When the First World War broke out, however, the card was altered to include a sign on the lawn in front of the palace that read: "For Rent or Sale-Can be Used for Housing Troops."

The crucial observation to make, however, is that both the 1899 Convention on Pacific Settlement and that Convention as it was amended in 1907 failed to play any significant reported role in the most significant event of the twentieth century: the First World War. Noted military historian John Keegan describes the impact of the war in these words: "The First World War inaugurated the manufacture of mass death that the Second brought to a pitiless consummation.... [I]t damaged civilisation, the rational and liberal civilisation of

${ }^{199}$ Hurl, supra note 64 , at 417.

${ }^{140}$ EAGLETON, supra note 127, at 226; see also T. J. LAWRENCE, THE PRINCIPLES OF INTERNATIONAL LAW 583 (6th ed. 1915).

${ }^{141}$ Great Britain, resolution on a court of arbitral justice, May 26, 1899, reprinted in HuLL, supra note 64, at 424.

${ }^{142}$ U.S. DEP'T OF STATE, PAPERS RELATINGTO THE FOREIGN RELATIONSOFTHE UNITED STATES 1899, at 518 (1901).

${ }^{143}$ A preface to the book reprinting that portion of Andrew White's autobiography dealing with the 1899 conference states: "the second conference made definite ... the meeting of a third ... and this means a fourth and a fifth." E. D. M., Preface to WHITE, CONFERENCE, supra note 64, at iii. 
the European enlightenment, permanently for the worse and, through the damage done, world civilisation also."144

All that Ivan Bloch had foreseen came about with a vengeance. The First World War claimed millions of lives. Of the German men born between 1892 and 1895, boys who ran and played during the Peace Conference of 1899, 35-37 percent would be killed in the war. ${ }^{145}$ The war devastated economies, tore at what social fabric there was, precipitated revolution in Russia in unexpected directions, and brought totalitarianism to at least Germany and Italy. That the Second World War is viewed as a result of the first is almost trite, but nonetheless true. Indeed, it seems that much of the twentieth century has been devoted to quieting the echoes of the guns of August 1914. ${ }^{146}$ Yet amid the constant sparks of European rivalries along colonial frontiers, the troubles in the Balkans, and the opening salvos of the "war to end all wars," the various options available under the Hague Convention were not used.

Shortly before the First World War, Norman Angell in The Great Mlusionvoiced sentiments similar to those of Bloch about war, but concluded that improvement will come "not from better intention, but from an acuter use of the intelligence of men, from hard mental work." ${ }^{147}$ Angell found it ironic that "surprise is expressed that such schemes [the Hague Peace Conferences] do not succeed." 148 By the end of the war, with ten million dead and thirty million wounded, many others would express similar views. Philip Kerr, who had observed the military planning in Britain firsthand, wrote, "Nor shall we abolish wars by passing pious resolutions ... or even in the long run by international conferences at Washington or The Hague." 149

In retrospect, the contours of the events set out above suggest that the 1899 Peace Conference did not have an opportunity to prevent the defining event of the twentieth century. The record shows the presence of extremely able leaders both within and outside the meetings. The inspiration to call the conference, the rigor of Bloch's work, and the commitment of various delegations amounted altogether to as bold and determined an effort as one might hope for. One could criticize the lack of preparatory work for the 1899 conference, but given the lack of change in negotiating positions even at the 1907 conference, no amount of planning would probably have significantly altered the work of the Third Commission in 1899.

The passage of time and the construction of memory tend to render those in the past either naive or shortsighted. Perhaps simply a consequence of hindsight's clarity, this temporal chauvinism renders the optimism of the peace movements quite naive, and the nationalistic opposition to arbitration of any kind a gross error. But there is no reason to believe that the range of beliefs and personalities involved in the 1899 conference was basically any different from those that can be seen in play today. The participants were as perceptive, as inspirational, and as foolish as statesmen and activists today, and one can only wonder what their reactions would be if they could observe the recent negotiations on the international criminal court and the land mines conventions.

Yet it does seem that the nineteenth-century proposition that an international court enjoying obligatoryjurisdiction could, through the force of public opinion, bring about a time

${ }^{14}$ JOHN KEEGAN, THE FIRST WORLD WAR 4, 8 (1999).

${ }^{115}$ See id. at 7.

${ }^{146}$ With the Cold War concluded, the Soviet Union broken apart, and the 20th century drawing to a close, it appears increasingly evident that the First World War "changed the course of history more than any other in modern times." Paul Kennedy, In the Shadow of the Great War, N.Y. REv. Books, Aug. 12, 1999, at 36, 36.

${ }^{147}$ Norman ANGell, The Great Illiusion: A Study of THE ReLATion OF MIITARY POWER to National ADVANTAGE 373 (4th ed. 1913).

${ }^{148} I d$. at 368 .

${ }^{149} \mathrm{Kerr}$, supra note 4, at 14. For Kerr's role during the war, see id. at 8. 
of peace would not be nearly as widely or enthusiastically accepted today. The history of the past century, both in negotiations and in practice, has led us to this difference in view. Perhaps the present time views war more complexly. At least, it apparently views international adjudication as only one, and even then a rare, tool in the box of international diplomacy.

The important corollary to this circumspect reappraisal of the peace movements' faith in an international court is that today the international community, at least as re:gards the use of force, expects less from the machinery of interstate adjudication. It is not viewed with the same unbridled expectations. ${ }^{150}$ This observation is all the more noteworthy when set alongside the growth in recent decades of international adjudicative bodies in other areas of international activity, for example, the legalization of the dispute resolution mechanism of the World Trade Organization and the establishment of the International Tribunal for the Law of the Sea.

After the First World War, the discussions and work of the Hague Peace Conferences constituted much of the basis for the creation of the Permanent Court of International Justice, which eclipsed to some extent its elder sister, the Permanent Court of Arbitration. A revival of the Permanent Court of Arbitration began in 1976, when its Secretary-General was designated in the UNCITRAL Rules of Arbitral Procedure as the one responsible for naming an appointing authority for arbitrations under the UNCITRAL Rules where the parties were unable to do so. Moreover, through the efforts of its immediate past SecretaryGeneral, Hans Jonkman, and a small group of talented advisers, the Permanent Court of Arbitration has enjoyed a structural renaissance over the past decade and has positioned itself to be an important jurisdictional complement to its younger sister, the International Court of Justice. ${ }^{151}$

\section{THREE ECHOES}

The 1899 Peace Conference formed a part of the growing organization of international society at the end of the nineteenth century and its tenor reflected the progressivism, confidence, and insecurities of that time. The intellectual continuation of the ideas and tensions manifested in the conference may be seen in the negotiation and structure of the League of Nations and the United Nations. As stated earlier, the 1899 conference was a point of inflection, a turn in the river, in the effort to move beyond ad hoc international arbitration to adjudication by a permanent international court, in the belief that this shift might avoid the horror of war. While it would be premature to say that international law has successfully navigated that turn, the universality of both international organization and international law has deepened significantly. Areas of contention certainly exist, but the limited range of contested subjects, and even the forms of argumentation about them, evidence the great extent of universality.

In considering the spirit of the 1899 Peace Conference, its traces across the twentieth century, and its possible trajectories into the next, at least three echoes can be heard.

\footnotetext{
${ }^{150}$ See generally Contributions of the Contr to the Resolution of International Tensions, in INCREASING THE EFFECTIVENESS OFTHE INTERNATIONAL COURT OFJUSTICE 77-100 (Connie Peck \& Roy S. Lee eds., 1997) (remarks of Carl-August Fleischhauer, Robert Jennings, Elisabeth Zoller, Conrad Harper, Keith Highet, Alain Pellet, Prosper Weil, Thio Su Mien, Hugh Thirlway, John Dugard, and Alberto Luis Davérède).

${ }^{151}$ See David D. Caron, The Permanent Court of Arbitration: 'Seeking the Most Effective Means of. . . a Real and Lasting Peace,'in CONIEMPORARYINTERNATIONALISSUES: OPPORTUNITIESATA TIMEOFMOMENTOUSCILANGE 166 (Proceedings of the Second Joint Conference of the American Society of International Law and the Nederlandse Vereniging voor Internationaal Recht, 1993) (remarks); see alsojeffrey Bleich, A New Direction for the PCA: The Work of the Expert Group, 6 LEIDENJ. INT'L L. 215 (1993). See generally Working Group on Improving the Function of the Court, The Permanent Court of Arbitration-New Directions (May 13, 1991) (report of meeting).
} 


\section{The Force of Public Opinion and the Stature of the Court}

The faith of the peace movements in the value of an international court rested in part on belief that the force of public opinion could sway governments, even avoid war. The force of public opinion, in turn, rested on the stature of the institution. The relationship of the force of public opinion to the stature of the institution holds true for all courts, but it is particularly true for international courts, which lack the coercive force of municipal tribunals and at times need the force of public opinion to be effective. ${ }^{152}$

The peace movements believed that this crucial element of public opinion would be greater if rulings came from a permanent court rather than ad hoc arbitration because these organizations viewed such a court as naturally enjoying greater stature. ${ }^{153}$ The court would be more open and an instrument not only of the parties, but also of the community itself. For example, the 1899 Convention provides that decisions issued by the Permanent Court of Arbitration are to be in writing, read publicly, and disseminated. ${ }^{154}$ In this way, the negotiators of that court, in today's parlance, sought to establish an institution whose transparency would strengthen its legitimacy and public support. The force of public opinion was also closely linked to the assumption that the stature of the court to be created would be above reproach.

Stature, however, encompasses many notions that need to be teased apart. Respect for a judicial institution turns on the perceived fairness of the substantive law to be applied; the degree of confidence in the independence, impartiality, and competence of the judges; and the quality of the judgments rendered. The Statute of the International Court of Justice calls

${ }^{152}$ Although our current view of how, and to what extent, public opinion plays a role in international affairs seems less simple than that expressed in 1899 , there is nonetheless widespread agreement today that it does exercise some influence. Ladd, ever optimistic, in 1840 declared that "moral power [was] increasing in a geometrical ratio and thus in the future nations will be more agreeable to follow and honor the court rulings." LADD, supra note 12 , at $5-7$. Similarly, Choate wrote that

it is still occasionally insisted that there is no sanction to the judgments of the permanent Court of Arbitration .... But here we have what may be regarded as the common judgment of mankind ... that henceforth, in obedience to the public opinion of all nations, the contending parties shall submit in good faith to the decision of the arbitral tribunal.

CHOATE, supra note 11, at 34 . Given the dramatically greater power of communication, an optimistic view today would probably be closer to that espoused by Sir Henry Maine in 1898. For Maine, "[ $t$ ]he truth is that an offender against the obligations of International Law is at present seriously weakened by the disapprobation he incurs." MAINE, supra note 3, at 221. It should also be acknowledged, however, that Maine's view is more optimistic than that held by many of today's realists. See, e.g., Geoffrey Best, Peace Conferences and the Century of Total War: The 1899 Hague Conference and What Came after, 75 INT'L AFF. 619, 631 (1999). But Maine, like a realist, believed that if the conflict was serious enough, then shame would notstop it. For Maine, force must stand behind the court, but the force of the "commonwealth of nations," in his view, while "immense and practically irresistible . . is badly distributed and not well directed, and ... is too often impotent, not only for the promotion of good, but for the prevention of acknowledged evil." MAINE, supra, at 222.

${ }^{133}$ How the normative expectations and legal knowledge of various public groupings play a role in international relations is the subject of much academic investigation at present. In contrast to the assumptions made a century ago, these investigations consider more subtle and complex causal pathways. See, e.g., JOAQUíN TACSAN, THE DYNAMICS OF INTERNATIONAL LAW IN CONFLICT RESOLUTION (1992). See also Laurence R. Helfer \& Anne-Marie Slaughter, Toward a Theory of Effective Supranational Adjudication, 107 YALE L.J. 273 (1997). One such pathway turns on the capacity of the authoritative knowledge of an institution, such as the International Court of Justice, to clarify the values and thinking of a range of actors and thereby strengthen a particular expression of public opinion. If we accept Maine's view that shame will not prevent a conflict where important matters are at stake, we should conclude that those directly involved in an important dispute are the least likely to be influenced by the authoritative legal knowledge that might emerge from an institution such as the International Court. Correspondingly, we should conclude that the force of a ruling of the Court will be felt most strongly by those states that are not directly involved. In this sense, the force of public opinion resulting from an opinion of the Court is perhaps greatest in the area of armed conflict when the opinion emanates from states and other actors that are not directly involved, yet are interested; that are strong, yet not isolationist. Commenting on the proposal of French economist Molinari for a League of Neutral Powers, Maine observed that "if war is ever to be arrested, it will be arrested by sacrifices on the part of those states which are neither at war nor desire to go to war." MAINE, supra note 3, at 224.

${ }^{154} 1899$ Hague Convention No. I, supra note 73, Arts. 52-53. 
for a strong judiciary when it reminds electors to bear in mind that judges of the Court "should individually possess the qualifications required, but also that in the body as a whole the representation of the main forms of civilization and of the principal legal systems of the world should be assured." ${ }^{155}$ Universality and individual stature combine in this important phrasing. Many gifted judges from all civilizations and the principal legal systems have served the Court and the international community. Both they and scholars of the Court have made a refrain of the call for the strongest judiciary possible because they particularly appreciate that this quality sustains the stature of the Court and the force of public opinion.

Likewise, because the legitimacy and authority of the Court ultimately rest on the quality of its judgments, commentators have sought to refine its deliberative process to make it a more exacting means of distilling the judges' combined wisdom. The traditions of collegial decision making vary among countries. It is unclear whether such variations are the cause, but-as one study concluded - "there is nearly universal dissatisfaction with portions of the Court's present deliberation process." 156 The challenge over the coming decades will be for the Court to affirm its fundamental role apart from ad hoc arbitration. Hans Corell, the UN Under-Secretary-General for Legal Affairs, recently noted that, in conversations with representatives of members of the Organization for Security and Co-operation in Europe, he found "that many held the view that there are so many methods and mechanisms for dispute resolution, that we really do not need any additional instruments." 157 In this marketplace of mechanisms, the question becomes, what does the International Court of Justice, as distinct from other mechanisms, do for the international community and how may it perform that task better? Perhaps the 1899 Hague Peace Conference provides guidance. Léon Bourgeois, schooled as a delegate to the 1899 and 1907 conferences, and later as a delegate to the Council of the League of Nations, stated at the opening meeting of the Committee of Jurists for the Permanent Court of International Justice on June 16, 1920:

The Court of Justice must be a true permanent Court. It is not simply a question of arbitrators chosen on a particular occasion, in the case of conflict, by the interested parties; it is a small number of judges sitting constantly and receiving a mandate, the duration of which will enable the establishment of a real jurisprudence on which public law may be built up. ... [T] hese judges will represent the truly international spirit, which is by no means, as some people pretend, a negation of the legitimate interests of each nation, but which is, on the contrary, the safeguard of these interests, within the very limits of their legitimacy. ${ }^{158}$

The quality of the judges as individuals and the process by which they collectively reach a judgment reside at the core of both the respect accorded the Court and the willingness of states to consent to its jurisdiction. In the context of a marketplace of mechanisms, the Court will need to earn the confidence of the international community through its actions in each and every case.

\footnotetext{
${ }^{155}$ International Court of Justice Statute, Art. 9.

${ }^{156}$ Richard B. Lillich \& G. Edward White, The Deliberative Process of the International Contr of Justice: A Preliminary Crilique and Some Possible Reforms, 70 AJIL 28, 37 (1976) (reviewing generally the historical development and present status of the deliberative process); see also Robert Y. Jennings, The Collegiate Responsibility and Authority of the International Court of Justice, in INTERNATIONAL LAW AT A TIME OF PERPLEXITY 343 (Yoram Dinstein ed., 1989); Mohammed Bedjaoui, The "Manufacture" of Judgments at the International Court of Justice, 3 PACE Y.B. INI"L L. 29 (1991); Edvard Hambro, The Reasons behind the Decisions of the International Court of Justice, 1954 CURRENT LEGAL PROBS. 213.

${ }^{157}$ Hans Corell, The Feasibility of Implementing The Hague/St. Petersburg Centennial Recommendations under the UN System, in PEACEFUL RESOLUTION OF MAJOR INTERNATIONAL DISPUTES: FURTHERING THIE OBJECTIVIS OF THIE FIRS I INTERNATIONAL PEACE CONFERENCE OF 1899, at 33 (1999).

${ }^{158}$ LEAGUE OF NATIONS O.J., Jul.-Aug. 1920, at 228, 230.
} 


\section{Recourse to the Court and Clarity as to the Basis of Decision}

A linked pair of questions at the Hague Conferences was the possibility of some measure of obligatory jurisdiction and the basis on which the Court would decide disputes covered by that jurisdiction. If one considers submitting a matter to the International Court of Justice, the stakes for those who must appear before it immediately become greater. Thus, in considering recourse to the Court in a specific instance or through acceptance of some measure of compulsory jurisdiction, a state is led to inquire into the basis of decision. Indeed, it can be said that the very creation of the institution makes specificity in the content of the likely applicable norm important. ${ }^{159}$ One therefore sees at the first Peace Conference not only a reluctance to entertain obligatory arbitration, a desire to attach "reservations" on important matters if such a scheme was adopted, and an attempt to seek agreement on only a circumscribed category of disputes; but also, in all these instances, discussion concerning the simultaneous need for codification of the substantive legal rule to be applied to such disputes. ${ }^{160}$

This linkage in 1899 between recourse to a court and the basis of decision appears to resonate in at least three ways today. First, when the question of some form or degree of compulsory jurisdiction for all states accepting the jurisdiction of the International Court of Justice arises again, attempts will very likely be made first to identify categories of disputes for which all states may be willing to accept such jurisdiction. Indeed, it might be said that this is precisely the situation at present, in that much of the compulsory jurisdiction agreed to for the Court pertains to disputes regarding the interpretation or application of various multilateral treaties, in each case a category of specific disputes. Similarly, the discussions among some of the permanent members of the Security Council in 1989 on a collective agreement to accept the Court's compulsory jurisdiction focused on a quite limited set of types of disputes.

Second, a court that views its mission as the progressive development of international law will undermine the willingness of some states to submit disputes to it. In their recent learned report on the occasion of the centennial of the 1899 Hague Peace Conference, ${ }^{161}$ Francisco Orrego Vicuña and Christopher Pinto made an important contribution. However, I very cautiously approach their suggestion that the International Court of Justice be given "a role that reaches beyond mere dispute settlement and puts the Court in a position to contribute to the development of the principles of international law governing the international society." 162 Andrew White, at the conclusion of the 1899 conference, made a similar, if somewhat more modest, observation in his diary: "There is also another gain,-incidental, but of real and permanent value; and this is the inevitable development of the law of nations by the decisions of such a Court of Arbitration composed of the most eminent jurists from all countries." ${ }^{168}$ But there is a crucially important difference between these two statements.

\footnotetext{
${ }^{159}$ See KeLSEN, supra note 1, at 145-48.

${ }^{160}$ The Committee of Jurists, in considering the law to be applied by the Permanent Court of International Justice, sidestepped the issue of the basis of decision by providing a method for the judges to follow in ascertaining the law, rather than restating the law at that moment; a method rather than a particular rule, i.e., application of the sources listed in Article 38 of the PCIJ Statute. Of course, to believe in a method, one must believe in those who will apply it, the first echo just discussed. And if one does not have confidence in the judges or the process, then a method approach may raise concerns that the judges possess too much authority in determining the content of the applicable norm, which in turn may deter acceptance of jurisdiction.

${ }^{161}$ Francisco Orrego Vicuña \& Christopher Pinto, The Peaceful Settlement of Disputes: Prospects for the Twenty-first Century (1999) (revised report prepared for the 1999 centennial of the first International Peace Conference). For the revised report, along with the preliminary draft and comments thereon, see <http://www.minbuza.nl/ English/f_sumnews14.html> (visited Dec. 13, 1999).

${ }_{162}$ Orrego Vicuña \& Pinto, supra note 161, para. 110.

${ }^{163}$ CHOATE, supra note 11 , at 39 (quoting 2 WHITE, AuTOBIOGRAPHY, supra note 64 , at 354 ).
} 
For White, the development of international law was an incidental benefic of a court's deciding cases. For Orrego Vicuna and Pinto, the Court's development of the principles of international law governing international society is a goal, and not merely a consequence of the performance of its primary task, that is, deciding cases before it in accordance with Article 36 of the Statute. Courts strengthen order both particularly and generally. They do so, however, not by acting as a surrogate legislature, but by adjudicating the specific case before them. To the extent that the World Court is viewed as being as concerned with the progressive development of law as it is with the correct resolution of the dispute before it, the concern of states over the basis of decision will correspondingly resurface and their consent to appear before it will probably be less forthcoming. The International Court of Justice contributes to the sound elaboration of international law, but to preserve its ability to do so in the long term it must make that contribution as a consequence of resolving individual cases and not as an object unto itself. ${ }^{164}$

Third, one must acknowledge that neither in 1899 nor today could the reluctance to agree to compulsory jurisdiction be explained as resulting merely from lack of confidence in the independence, impartiality, or competence of the judges, or in their collective decision-making process, or uncertainty as to the norms to be applied. Rather, one senses that many states entertain considerable doubt that the application of a necessarily generalized rule of law, instead of diplomacy, to the specific incident is the correct approach when issues assume fundamental importance to the state or the international community-when the interests at stake are too substantial or the history of wrongs too long. For states that hold this doubt, it is important that the law be able to recognize its own limitations, its own human origin. Professor Abi-Saab once remarked to me that in the Islamic world, a rug maker always incorporates a flaw in his work, for otherwise he would be guilty' of the hubris of striving for the perfection held only by God. The scope of international law has grown tremendously over the past century and the Court's potential subject-matter reach has grown correspondingly. Yet, although few would suggest that international law provides the appropriate answer for all of the disputes that could come before the Court, the possibility at present that it will abstain when faced with a dispute otherwise within its jurisdiction is extremely small. The international community and the International Court of Justice have come a long way from the negotiations in 1899 when the delegates proposed and debated self-judging exceptions to jurisdiction in the case of national interests or honor. Such exceptions amount to the complete negation of a legal system and the Court today correctly rejects objections to jurisdiction that in essence would resurrect such loopholes.

Nevertheless, the adamancy with which the Court now eschews any discussion of judicial abstention seems to me more a weakness than a strength. The Court appears to be defending itself from slipping into a weaker past. In time, it can be hoped that a more confident Court will recognize that there may be limits to its ability to render a reasoned judgment and that the decision to abstain, not dismiss, can be a virtue. ${ }^{165}$ This concern with the adequacy of law in an incomplete legal system manifested itself in the problem of "peaceful change," discussed extensively in the interwar period, and is an aspect of the prohibition on non liquet, which once again has gained widespread attention. Indeed, as the substantive realm of international law becomes greater and the adjudicatory institutions that apply it become stronger, so also will there emerge a search for a balance between the jurisdiction of the Court and that of national systems-a balance sought in all federative structures and present in the subsidiarity debate in Europe.

\footnotetext{
${ }^{164}$ See Ted L. Stein, Tribunal Decisions: The Reason for Reasons, MEALEx's LITIGATION REP.: IRAVIAN CLAIMS, May 4,1984 , at 547 .

${ }^{165}$ See generally ALEXANDER BICKEL, THE LEAST DANGEROUS BRANCH (1962).
} 


\section{Bringing about the Potential for Institutional Adaptation}

Although the delegates came to view the Hague Conferences as a process rather than an event, it is not clear that they thought through the implications of a process for the form of their work. In a process, one should seek results that may be amenable to change at a later point in the process. However, in the space of only two conferences, the delegates succeeded in creating two versions (1899 and 1907) of the Hague Convention for the Pacific Settlement of International Disputes, the two Conventions existing side by side with different sets of contracting parties. Indeed, a recent report on improving the workings of the Permanent Court of Arbitration noted that the existence of two Conventions with different state parties gave rise to unnecessary confusion, even though no practical problems had surfaced as of yet.

The process begun in The Hague has continued in other venues, but the efforts that followed have also not yielded particularly flexible or adaptable institutions. Another striking feature of the report by Orrego Vicuna and Pinto is that it presents numerous recommendations for the International Court of Justice that would require amending the UN Charter. ${ }^{166}$ Both its authors and commentators on that report, however, also emphasize the great difficulty of gaining any amendment of the Charter. ${ }^{167}$ Indeed, because of the inflexibility of the Court's Statute, innovation in the global system for the peaceful settlement of disputes is gained primarily by creating complicating and, one hopes, complementary structures. ${ }^{168}$

The difficulty of amending the structure of the International Court of Justice impedes prognostication about its future. New directions, realistic if only in the sense that they are remotely possible, cannot be precisely perceived and are rarely satisfying because the system is perhaps necessarily, but nonetheless excessively, rigid. Like the Winchester Mystery House (to which rooms were added, but were never altered or removed), the international system of dispute resolution every several years acquires new mechanisms, duplicating to some extent existing ones without altering the basic structure of what should be its core-the International Court of Justice. The century of international organization is beginning to show its age, and the United Nations itself appears least able of all to adapt formally to new circumstances. The international diplomatic community faces the challenge of devising a method for the Court to evolve as needed, while simultaneously providing security to expectations of states regarding institutions in which they participate.

\section{CONCLUSION}

If the realist tends to see only the constraints of the present, then the idealist tends to see only the possibilities of tomorrow. Both strains of thought inform great leaders and in turn can often be found in the law. The two strands can be seen repeatedly in the rhetoric of the Hague Conferences and remain so timely that one can easily imagine the discussions to be taking place today. The international law scholar Luis Drago foresaw at the second Hague Conference that,

\footnotetext{
${ }^{166}$ Such proposals are in numerous places in the Orrego Vicuña and Pinto report, supra note 161. Section III, in particular, may be looked to in this regard, It should be noted that Orrego Vicuna and Pinto believe that some of their suggestions would not necessarily require formal amendment to the Charter but might be achieved through judicial interpretation of the Charter. See Orrego Vicuña \& Pinto, supra, §III.4, para. 122.

${ }^{167}$ Although the Statute of the International Court of Justice "forms an integral part of" the UN Charter (Article 92), it contains its own provisions on amendment. These articles (Article 69 in particular), however, provide as a general rule that "[a]mendments to the present Statute shall be effected by the same procedure as is provided by the Charter of the United Nations." As to amendment of the UN Charter, see Articles 108, 109.

${ }^{168}$ See Jonathan I. Charney, Is International Law Threatened by Multiple International Tribunals? 271 RECUEIL DES COURS 105 (1998); Symposium Issue, The Proliferation of International Tribunals: Piecing together the Puzzle, 31 N.Y.U. J. INT'L L. \& POL. 679 (1999).
} 
to the civilization which is supported by weapons, [there] shall succeed, in a more or less distant time, a civilization founded on arbitration and justice, a superior civilization which is neither force, nor power, nor riches, but rather the tranquil triumph of justice for the weak as well as for the strong. ${ }^{169}$

The record of speeches indicates that Andrew White, the head of the U.S. delegation in 1899, was drawn to such rhetoric. Other members of his delegation, particularly Captain Mahan, were not as enchanted by visions of the future. Although frustrated on occasion by Mahan's recognition of the needs of the present, White emphatically acknowledged his appreciation of it. At the close of the conference, White wrote in his diary: "Still, [Captain Mahan's] views have been an excellent tonic; they have effectively prevented any lapse into sentimentality. When he speaks the millennium fades and this stern, severe, actual world appears." ${ }^{170}$

The 1899 Peace Conference set in motion the evolution from the purely ad hoc arbitral tribunals of the nineteenth century to the wide range of mechanisms, including international courts, present at the end of the twentieth century. That evolution circles constantly around a tension between party autonomy and community interest, between consent to appear and obligatory jurisdiction, and between caution as to the integrity of the process and faith in the value of peaceful settlement.

The creation in the twentieth century of the Permanent Court of International Justice and its successor, the International Court of Justice, is a continuation, indeed a triumph, of both the aspirations and the concerns that were voiced at the 1899 Hague Peace Conference. The core issues that are likely to be confronted over the coming decades can be found in the discussions of that conference. The stature of the International Court of Justice, like that of all permanent courts, will rest on the quality of its judgments and thus on its judges and how they conduct their deliberations. If there is any move to make the compulsory jurisdiction of the Court universal, it will not come in the form of mandatory general acceptance but, rather, as a carefully enumerated set of applicable disputes. As any set of disputes becomes subject to compulsory jurisdiction, the details of the applicable law will grow in importance and ultimately rules of prudential abstention may be reexamined. Finally, and most fundamentally, great innovation will be required to devise a system of peaceful resolution of disputes that is both sufficiently fixed to secure the expectations of participating states and sufficiently adaptable to grow with the community it seeks to serve.

${ }^{169}$ Speech of Dr. Luis M. Drago, supra note 135, at 340-41.

${ }^{170} 2$ WHITE, AUTOBIOGRAPHY, supra note 64, at 347 (entry for July 29, 1899). 